\title{
De novo transcriptome of Taverniera cuneifolia (Roth) Ali.
}

\author{
Talibali Momin ${ }^{1}$, Apurva Punvar², Harshvardhan Zala ${ }^{3}$, Garima Ayachit ${ }^{2}$, \\ Madhvi Joshi' ${ }^{2}$ Padamnabhi Nagar ${ }^{1}$. \\ ${ }^{1}$ Department of Botany, Faculty of Science, The Maharaja Sayajirao University of Baroda -390002. \\ ${ }^{2}$ Gujarat Biotechnology Research Center (GBRC), Department of Science and Technology, Govt. of \\ Gujarat. Gandhinagar 382011. \\ ${ }^{3}$ Department of Genetics and Plant Breeding, C. P. College of Agriculture, Sardarkrushinagar \\ Dantiwada Agricultural University, Sardarkrushinagar - 385 506, Gujarat - INDIA
}

*Corresponding author:

Padamnabhi Nagar:drnagar@gmail.com

Talibali Momin: talib429gmail.com

Department of Botany,

Faculty of Science,

The Maharaja Sayajirao University of Baroda -390002. 


\section{ABSTRACT}

Taverniera cuneifolia has been described as a potent substitute of Licorice in India. It has been used as an expectorant, anti-inflammatory, anti-ulcer, wound healing, blood purifier etc. Glycyrrhizin is one of the most useful bioactive sesquiterpenoid present in this plant. The present study aim to carry out transcriptome analysis in root tissue of Taverniera cuneifolia to identify specific functional genes involved in the biosynthesis of secondary metabolites. The root transcriptome sequencing of Taverniera cuneifolia resulted in a total of $\sim 7.29 \mathrm{~Gb}$ of raw data and generated 55,991,233 raw reads. The high quality reads were de novo assembled by Trinity assembler followed through CD-HIT resulted into 35,590 "Unigene" transcripts with an average size of $419 \mathrm{bp}$. The unigenes were analyzed using BLAST2GO resulted in 27,884 (78.35\%) transcript with blast hits, 22,510 (63.25\%) transcript with mapping and 21,066 (59.19\%) transcript with annotation. Functional annotation was carried out using NCBI's non-redundant and Uniprot databases resulted in the identification of 21,066 (59.19\%) annotated transcripts and GO assigned to 24751 (69.54\%) transcripts. The gene ontology result shows maximum sequences match with Biological Processes (48\%), Molecular Function (27\%) and Cellular components (23\%). A total of 289 metabolic enriched pathways were identified, which included pathways like Sesquiterpenoid and triterpenoid pathway which were involved in synthesis of secondary metabolite Glycyrrhizin biosynthesis. The enzymes, squalene monooxygenase, farnesyl-diphosphate farnesyltransferase, beta amyrin synthase, beta-amyrin 24-hydroxylase, were identified by functional annotation of transcriptome data. There were several other pathways like terpenoid backbone biosynthesis, steroid biosynthesis, Carotenoid biosynthesis, Flavonoids biosynthesis etc. which have been reported first time from this plant. Transcription factors were predicted by comparison with Plant Transcription Factor Database, and 1557 trancripts belonging to 85 trancription factor families were identified. This transcriptome analysis provided an important resource for future genomic studies in Taverniera cuneifolia, therefore representing basis in further investigation of the plant. 


\section{De novo transcriptome analysis of Taverniera cuneifolia (Roth) Ali.}

\section{ABSTRACT}

Taverniera cuneifolia has been described as a potent substitute of Licorice in India. It has been used as an expectorant, anti-inflammatory, anti-ulcer, wound healing, blood purifier etc. Glycyrrhizin is one of the most useful bioactive sesquiterpenoid present in this plant. The present study Root transcriptome sequencing of Taverniera cuneifolia resulted in a total of $\sim 7.29$ Gb of raw data and generated 55,991,233 raw reads. The high quality reads were de novo assembled by Trinity assembler followed through CD-HIT resulted into 35,590 contigs transcripts with an average size of 419 bp. Functional annotation was carried out using NCBI's non-redundant and Uniprot databases resulted in the identification of 21,066 annotated transcripts and GO assigned to 24,751 transcripts. The gene ontology result shows maximum sequences match with Biological Processes (48\%), Molecular Function (27\%) and Cellular components (23\%). A total of 289 metabolic enriched pathways were identified, which included pathways like Sesquiterpenoid and triterpenoid pathway which were involved in synthesis of secondary metabolite Glycyrrhizin biosynthesis. The enzymes, squalene monooxygenase, farnesyl-diphosphate farnesyltransferase, beta amyrin synthase, beta-amyrin 24-hydroxylase, were identified by functional annotation of transcriptome data. There were several other pathways like terpenoid backbone biosynthesis, steroid biosynthesis, Carotenoid biosynthesis, Flavonoids biosynthesis etc. which have been reported first time from this plant. Transcription factors were predicted by comparison with Plant Transcription Factor Database, and 1557 trancripts belonging to 85 trancription factor families were identified. This transcriptome analysis provided an important resource for future genomic studies in Taverniera cuneifolia, therefore representing basis in further investigation of the plant.

\section{Significance}

Licorice (Glycyrrhiza glabra roots) is used as traditional Chinese herbal medicines in majority of formulations. Licorice is also used in Industries like food, herbal and cosmetics etc. due to its high demand in the market it is imported from foreign countries and is not available locally of superior quality (Liu et al., 2015). In India, Taverniera cuneifolia has been described as a potent substitute of Licorice, it has been quoted in ancient books like Charak Samhita during the Nigandu period (Kamboj, 2000) and Barda dungar ni Vanaspati ane upyog (Thaker 1910). It has been used as an expectorant, anti-inflammatory, anti-ulcer, 
wound healing, blood purifier etc. Transcriptomic studies will assist in understanding the basic molecular structure, function and organization of information within the genome of Taverniera cuniefolia. This study will help us to identify the key metabolites their expressions and genes responsible for their production.

Key words: Taverniera cuneifolia, De novo assembly, Transcriptome, Licorice, Glycyrrhizin, Sesquiterpenoid pathway.

Bioproject ID: 388043

This Transcriptome Shotgun Assembly project has been deposited at DDBJ/ENA/GenBank under the accession GJAF00000000. The version described in this paper is the first version, GJAF01000000.

\section{Sequences Accession numbers: SRR5626167}

\section{Introduction}

India is rich in many potential medicinal plants, Glycyrrhiza glabra popularly known as Liquorice has been used in the traditional formulation. A licorice (Glycyrrhiza glabra) root has been used in more than 1200 formulations in traditional Chinese herbal medicines as major formulations. There are many essential uses of this plant in industries like food, herbal, cosmetics, nutraceuticals etc. (Pastorino et al., 2018). Due to its high demand in the market, it is imported from foreign countries and not available locally of superior quality. In India, Taverniera cuneifolia has been described as a potent substitute for Licorice. Glycyrrhizin is one of the most useful bioactive sesquiterpenoid present in this plant.

Taverniera cuneifolia belong to fabaceae family, the third largest family of flowering plants, with over 800 genera and 20,000 species. The three major subfamilies include Mimosaceae, Papilionaceae and Caesalpiniacea. The pea (Pisum sativum L.) was the model organism used in Mendel's discovery (1866) and is the foundation of modern plant genetics. The phylogenetic differ greatly in their genome size, base chromosome number, ploidy level and reproductive biology. Two legume species in the Galegoid clade, Medicago truncatula and Lotus japonicus, from Trifolieae and Loteae tribe respectively, were selected as model system of studying legume genomics and biology. There are many other legumes that have been studies like the soybeans, the most widely grown and economically important legume 
whose genome has been available since 2010.The common bean (Phaseolus vulgaris) the most widely grown grain legume whose genome is available since 2014. Many more legumes have been sequenced since (Smýkal, P. et al., 2020).

Taverniera cuneifolia is an important traditional medicinal plant of India as mention in Charak Samita in Nigantu period. It is often referred to as Indian licorice having the same sweet taste as of Glycyrrhiza glabra (commercial Licorice) (Zore, 2008). The genus Taverniera has sixteen different species (Roskov et al., 2006). It is endemic to North-east Africa and South-west Asian countries (Naik, 1998). Licorice is used as important traditional Chinese medicine with many clinical and industrial applications like Food, Herbal medicine, cosmetics etc. (Liu et al. 2015). Taverniera cuneifolia locally known as Jethimad is used by the tribal's of Barda Hills of Jamnagar in Western India (Saurashtra, Gujarat) as a substitute for Licorice or in other words, the Plant itself is considered to be Glycyrrhiza glabra (Nagar, 2005). Many pharmacological benefits of the plants have been reported earlier like expectorant, blood purification, anti-inflammatory, wound healing, anti-ulcer and used in treating spleen tumors (Thaker, Manglorkar and Nagar, 2013).

At the Biochemical level, Taverniera cuneifolia has shown the presence of alkaloids, flavonoids, tannins, proteins, reducing sugar and saponins. The presence of oil content in the seeds of Taverniera cuneifolia showed polyunsaturated fatty acids, monounsaturated fatty acids and saturated fatty acids (Manglorkar, 2016). Taverniera cuneifolia has been assessed very less on phytochemical basis there are only few attempts to characterize this plant at molecular level. Taverniera cuneifolia has eight numbers of chromosomes (Perveen and Khatoon, 1989). There is limited information on genetic for this plant on NCBI. Fifteen proteins have been reported from this plants which includes ribosomal protein L32, maturase, photosystem 1 assembly protein Ycf4, cytochrome b6/f complex subunit VIII, D1 protein, photosystem 2 protein M, MaturaseK, ribulose-1,5-bisphosphate carboxylase/oxygenase large subunit, Triosephosphate translocator, Phosphogluconate dehydrogenase, UDPsulfoquinovose synthase, RNA polymerase beta subunit (Liu et al., 2017).

The current investigation was focused on the most valuable secondary metabolite, Glycyrrhizin and other important secondary metabolites. This experiment provides the indepth characterizations of this plant. Based on the above facts attempts have been made to identify the genes of various metabolic pathways in Taverniera cuneifolia through root transcriptome sequencing. The study will give scientific insight into the molecular network of Taverniera cuneifolia. 
Materials and Methods

\section{Plant material and RNA isolation}

101

102

103

104

105

106

107

108

109

110

111

Taverniera cuneifolia plant was collected from Kutch, Gujarat, India (23.7887 N, 68.79580

E) from its natural habitat near the area of Lakhpat. The tissue of the plant, i.e., roots were cleaned with water than with ethanol and stored in RNA later solution (Qiagen) for longerterm storage. It was then shifted to $-20^{\circ} \mathrm{C}$ in the refrigerator. The total RNA was isolated from the root tissues of the Plant using the RNeasy Plant Mini Kit (Qiagen) following the manufacturer's instructions. The integrity of the RNA was assessed by formaldehyde agarose gel electrophoresis. Total RNA was quantified by using a Qiaxpert (Qiagen), Qubit 2.0 fluorometer (Life Technologies, Carlsbad, CA, USA) and Qiaxcel capillary electrophoresis (Qiagen). RNA integrity number (RIN) was higher than approx. 7.0 for the sample.

\section{cDNA library preparation and Sequencing}

Ribosomal RNA depletion was carried out using a RiboMinus RNA plant kit for RNA- Seq (Life Technologies, C.A). mRNA fragmentation and cDNA library was constructed using an Ion total RNA-Seq kit v2 (Life Technologies, C.A), further purified using AMpure XP beads (Beckman coulter, Brea, CA, USA). The library was enriched on Ion sphere particles using Dynabeads MyOne Streptavidin C1 using standard protocols for the Ion Proton sequencing. The raw transcriptome data have been deposited in the sequence read archive (SRA) NCBI database with the accession number SRR5626167. This Transcriptome Shotgun Assembly project has been deposited at DDBJ/EMBL/GenBank under the accession GJAF00000000.

\section{RNA-Seq data processing and De novo assembly}

Quality control of raw sequence reads was filtered to obtain the high-quality clean reads using bioinformatics tools such as FASTQCv.0.11.5 using a minimum quality threshold Q20 (Andrews, 2010). The clean reads were subjected to de novo assembly using the Trinity v2.4.0 (Grabherr et al., 2011) software to recover full-length transcripts. The redundancy of 
126 Trinity generated contigs were clustered for removing duplicate reads with $85 \%$ identity using CD-HIT v4.6.1 (Li and Godzik, 2006).

\section{Functional annotation of transcripts and classification}

130

131

132

Functional characterization of assembled sequences was done by performing BlastX of contigs against the non-redundant (nr) database, (https://www.ncbi.nlm.nih.gov/) using an evalue cut-off of 1E-5 followed by further annotation was carried out using Blast2GO (Conesa and Gotz, 2005). Gene Ontology (GO) study was used to classify the functions of the predicted coding sequences. The GO classified the functionally annotated coding sequences into three main domains: Biological process (BP), Molecular function (MF) and Cellular component (CC). Using the Kyoto encyclopedia of genes and genomes (KEGG) (Kanehisa and Goto, 2000) pathway maps were determined. Further, KEGG Automated Annotation Server (KAAS) was used for pathway mapping in addition to Blast2GO (Moriya et al., 2007) for assignment and mapping of the coding DNA sequence (CDS) to the biological pathways. KAAS provides functional annotation of genes by BLAST comparison against the manually curated KEGG genes database.

\section{Identification of transcription factors families}

Transcription factors (TFs) were identified using genome-scale protein and nucleic acid sequences by analyzing InterProScan domain patterns in protein sequences with high coverage and sensitivity using PlantTFcat analysis tool (http://plantgrn.noble.org/PlantTFcat/) tool (Dai et al., 2013).

\section{SSR prediction}

Simple sequence repeats (SSRs) were identified using the MISA tool (Microsatellite; http://pgrc.ipk-gatersleben.de/misa/misa.html). We searched for SSRs ranging from mono to hexanucleotide in size. The minimum repeats number 10 for mononucleotide, 6 for Dinucleotide and 5 for trinucleotide to hexanucleotide was set for SSR search. The maximal number of bases interrupting two SSRs in a compound microsatellite is 100 i.e. the minimum distance between two adjacent SSR markers was set 100 bases. 


\section{Results and Discussion}

\section{Transcriptome Sequencing and De novo assembly}

159 The total RNA of two root samples along with RIN value more than 7.0, converted to cDNA 160 library using Ion Total RNA-Seq kit v2 (Life Technologies, C.A), further purified using 161 Ampure XP beads (Beckman coulter, Brea, CA, USA). The library was enriched on Ion sphere particles using Myone C1 Dynabeads. A total of 7.29 gb of raw data was generated using standard protocols for the Ion proton sequencing (Table 1). The good quality roots of Taverniera cuneifolia were used for the RNA sequencing, and a total of 55,991,233 reads containing 7,286,727,421 bases were generated. The raw reads were subjected to quality check by FastQC tool and the average base quality was above Q20. De novo transcriptome assembly resulted in 36,896 reads assembled and the final assembly of 35,590 unique highquality reads was prepared using CD-HIT at 85\% sequence similarity, with N50 value of 441 bp. The average GC content of $43 \%$ and average contigs length of 419.45 bp was obtained for Taverniera cuneifolia. The statistics of transcriptome sequencing and assembly generated by Trinity assembler as given (Table 2).

A total of 35,590 transcripts (contigs) assembled by Trinity were subjected to functional annotation using different databases like the Nr Protein database, KEGG, UniProt, etc. GO terms were assigned to transcripts (Supplementary Fig. S2). All transcripts were screened for similarity to a known organism based on the data of species-specific distribution, and it can be concluded that the transcript showed the highest blast hits with Medicago truncatula $(18,734,52.63 \%)$ followed by Cicer arietinum (16,044, 45.08\%) and Glycine max (15,991, 44.93\%). A total of 10590 (29.75\%), 8642 (24.28\%), 8549 (24.02\%), 8399 (23.59\%) contigs were found to be similar to Cajanus cajan, Glycine soja, Trifolium pratense, Trifolium subterraneum, respectively (Figure 1). The functionally annotated transcripts $(27,884$, 78.34\%) of Taverniera cuneifolia were classified using Blast2GO into three main domains; Biological processes, Cellular component and Molecular function gene ontology (Table S1). Among them the most abundant were the Biological processes consisting of 44,395(48.8\%) sequences followed by different Molecular Function consisting of 25,025 (27.5\%) sequences and last the cellular components consist of 21,508 (23.6\%) sequences (Figure 2, 3, 4). The 
annotated transcripts were subjected to the Kyoto encyclopedia genes and genomes (KEGG) pathway wherein the transcripts were linked to enzymes found in a large number of pathways available in KEGG. The maximum number of annotated transcripts assigned to hydrolases, followed by transferases and oxidoreductases class of enzymes (Figure 5).

\section{Gene ontology classification}

The contigs were further annotated by Blast2Go software with assembled 27,884 transcripts GO terms and divided into three broad categories as Biological Processes (44,395[49\%]), Molecular Function (25,025[27\%]) and Cellular Component (21,508[24\%]) category (Table S1).

The Biological Processes were the most abundant component of GO terms. Among the 44,395 Biological Processes, the maximum number of contigs i.e. represented "Biological process,” followed by “Metabolic process” and “Cellular process” (Figure 2).

A total of 25,025 transcripts were associated with the Molecular function and a relatively large no of the transcript was associated with "Molecular function" followed by "Catalytic activity” and “Binding”, respectively ”(Figure 3).

In addition, Cellular Component a total of 21,508 transcripts were associated with the "Cellular component" as the highest match followed by "Cell" and "Cell part" respectively”(Figure 4).

\section{Pathway Annotation by KEGG}

Kyoto Encyclopedia of Genes and Genomes (KEGG) serves as knowledge source to perform functional annotation of the genes. The KEGG represents various biochemical pathways for the genes associated with it. Approximately 289 pathways were annotated and among them, Metabolic pathways (102), Biosynthesis of secondary metabolites (55), Microbial metabolism in diverse environment (22) showed the maximum hit with the database. Some of the important pathways from this plant are discussed below which have been reported with the gene and ko-id. (Table S2).

Terpenoids (isoprenoids) represent the largest and most diverse class of chemicals among the myriad compounds produced by plants. Moreover, the ecological importance of terpenoids has gained increased attention to develop strategies for sustainable pest control and abiotic stress protection. The gene that has shown in this plant includes Terpenoids 
backbone biosynthesis (ko00900) (Supplementary Fig. S3). which includes three gene, ko:K03526 gсpE; (E)-4-hydroxy-3-methylbut-2-enyl-diphosphate synthase [EC:1.17.7.1 1.17.7.3], ko:K05356 SPS; all-trans-nonaprenyl-diphosphate synthase [EC:2.5.1.84 2.5.1.85], ko:K15889 PCME; prenylcysteine alpha-carboxyl methylesterase [EC:3.1.1.-]. Monoterpenoid biosynthesis having two gene ko: K21373 UGT8; 7-deoxyloganetic acid glucosyltransferase [EC:2.4.1.323], ko:K21374 UGT85A23_24; 7-deoxyloganetin glucosyltransferase [EC:2.4.1.324] and Diterpenoid biosynthesis (ko00904) includes ko:K05282 GA20ox; gibberellin-44 dioxygenase [EC:1.14.11.12].

Sesquiterpenoid and triterpenoid biosynthesis (ko00909) (Supplementary Fig. S4). which includes three gene namely ko:K00801 FDFT1; farnesyl-diphosphate farnesyltransferase [EC:2.5.1.21], ko:K15813 LUP4; beta-amyrin synthase [EC:5.4.99.39], ko:K20658 PSM; alpha/beta-amyrin synthase [EC:5.4.99.40 5.4.99.39]. This are the gene on further reactions like oxidation and reductions leads to the production of Glycyrrhizin that is important secondary metabolites as mention above.

Carotenoid biosynthesis (ko00906) (Supplementary Fig. S5) includes ko:K09842 AAO3; abscisic-aldehyde oxidase [EC:1.2.3.14], ko:K09843 CYP707A; (+)-abscisic acid 8'hydroxylase [EC:1.14.14.137], ko:K14595 AOG; abscisate beta-glucosyltransferase [EC:2.4.1.263].

\section{Ubiquinone and other terpenoid-quinone biosynthesis (ko00130) (Supplementary Fig. S6)} include ko:K03809 wrbA; NAD(P)H dehydrogenase (quinone) [EC:1.6.5.2].

Zeatin biosynthesis (ko00908) (Supplementary Fig. S7) includes ko:K00791 miaA; tRNA dimethylallyltransferase [EC:2.5.1.75], ko:K13496 UGT73C; UDP-glucosyltransferase 73C [EC:2.4.1.-].

Flavonoid biosynthesis (ko00941) (Supplementary Fig. S8) inludes ko:K13065 E2.3.1.133; shikimate O-hydroxycinnamoyltransferase [EC:2.3.1.133].

\section{Candidate genes involved in biosynthesis pathways}

Among the 35,591 transcripts that have been annotated using different database, we have identified six gene that play important role in the biosynthesis pathway of Glycyrrhizin production from Taverniera cuneifolia (Table S3). Each six different gene includes in formation of Glycyrrhizin. 
There were 4912 unigenes hypothetical protein predicted from this plant, of which 30 unigenes that had a hit length above 400 were noted (Table S4). 94 unigenes that predicted Cytochrome P450 family protein from this plant, of which 17 unigenes with a hit length above 150 were noted (Table S5).

\section{Discussion}

Secondary metabolites have key role in providing the defense mechanism to plants against stresses and these metabolites have very important role in many economic important like industries, pharma sector etc (Pagare et al., 2015). There has been no molecular data recorded for this plant as such. The new advancement in the field of omics technologies has led to high-throughtput sequencing data which lead us to prediction of genes, enzymes, complex pathways. (Metzker,2010). De novo of many medicinally important plants such as Saussurea lappa (Bains, S et al, 2018), Vigna radiate L (Chen, H et al, 2015), Glycyrrhiza glabra (Chin,Y et al, 2007 ), pigeonpea Cajanus cajan ( L .) Millspaugh (Dutta, S. et al, 2011), Dracocephalum tanguticum (Li, H., Fu, Y., Sun, H., Zhang, Y., \& Lan, X., 2017) etc. have reported the trancripts involved in active metabolite production using NGS technology.

Transcriptome analysis has proved to be one of the advanced methods for the identification of gene expressing in different pathways of metabolism, growth, development, response towards stress, cell signaling etc. This has help in classifying and categorization different role in secondary metabolic compound. Glycyrrhizin, a well-known secondary metabolite that is found in roots of Licorice has same property that is been found in the roots Taverniera cuneifolia which has many uses as described above. A whole transcriptome analysis of root of Taverniera cuneifolia has opened the unique transcripts which are reported first time from this plant to be involved in the pathways of primary and secondary metabolism (Sharma, Kumar, Beriwal, et al, 2019).

The de novo assembled transcripts of Taverniera cuneifolia were mapped to non-redundant protein database using blastx tool. A total of 35,590 transcripts annotated to the database showed the maximum similarity with Medicago truncatula [(18,734) $52.6 \%$ followed by Cicer arietinum [(16,044) 45\%] and Glycine max [(15,991) 44.9\%] and so on, which belong to same family Fabaceae order fabales.

\section{Main metabolism-related gene of Taverniera cuneifolia.}


Glycyrrhizin is triterpenoid-saponin produced in Licorice roots. It is synthesized via the cytosolic melvonic acid pathway for the production of 2,3-oxidosqualene, which is then cyclized to $\beta$-amyrin by $\beta$-amyrin synthase (bAS). Then, $\beta$-amyrin undergoes a two-step oxidation at the C-30 position followed by glycosylation reactions at the C-3 hydroxyl group to synthesize glycyrrhizin as shown in (Supplementary Fig. S9)(Seki et al 2008, 2011). Taverniera cuneifolia also known as Indian Licorice can be used as substitute of Glycyrrhiza glabra as it has same features that of this plant. This plant contains varieties of different compound that can be used in future research like triterpenoids, flavonoids, polysaccharides etc, which have been reported first time from this plant. Among them Glycyrrhizin is a primary focus compound that has many economic importance use in different fields. In our experiment we have compared the enzymes and genes for the production of Glycyrrhizin with proposed pathway for biosynthesis of Glycyrrhizin by (Seki et al, 2011), In which Glycyrrhizin is produce by a series of chemical reaction i.e. oxidation of different compound associated with Melvanoic Acid pathway. In this particular pathway there are series of chemical reaction by which Farnesyl diphosphate (FPP) molecule catalyzed by squalene synthase (SQS) originating Squalene. There are fifteen different transcripts that we have found in our plants that are associated for the production of squalene and then by oxidation by squalene epoxidase (SQE) to 2, 3 - oxidosqualene to form $\beta$ - Amyrin. There are five gene identified from our plant that catalyzed by bAS i.e $\beta$ - Amyrin synthase to form $\beta$ - Amyrin. Further $\beta$ - Amyrin goes into various oxidation reaction with the help of Beta-amyrin 11oxidase /CYP88D6 and 11-oxo-beta-amyrin 30-oxidase/CYP72A154 to form Glycyrrhetinic acid. The last step includes conversion of glycyrrhetinic acid to glycyrrhizin which includes glycosylation steps in which different enzymes related to UDP-glycuronosyl transferases family are included. There were 32 different UDP-glycuronosyl genes which have been identified from our plant that led to last reaction given in table (Table S3).

At this point Taverniera cuneifolia have not been intensively studied and there as such no any reports that showed the details about the enzymes associated in the Glycyrrhizin pathway we have associated with reference pathway proposed by (seki et al 2008, 2011). As there has been no proper investigation for the pathway for glycyrrhizin known till today.

We have extensively worked upon the proteins which we have opted from our data of Taverniera cuneifolia. Approx. 4912 genes have been isolated that showed different proteins reported firstly from this plant among them the details have been provided in (Table S4) (we have approx. shown only those hypothetical proteins whose hit length is above 400 bases). In 
our studies we also found that there were more than 90 transcripts that showed the function related to Cytochrome P450 family protein. This protein has an immense ability to synthesis many new molecules required in the system to function and cope up with.

\section{Identification of SSR markers and Transcription factors}

The potential SSR from mono to hexanucleotide were predicted using MISA Perl script. A total of 35,590 unigene sequences were examined and 2912 SSR were obtained. It was found that only 2454 number of sequences were containing SSRs. Further, only 365 sequences contained >1 SSR marker and 265 were present in compound form. Tri-nucleotide represented the maximum numbers of SSRs (1291), followed by Mono-nucleotide (832) and then Di-nucleotide (597) (Table 3). The analysis of the transcripts revealed 1557 unique transcripts belonging to 85 transcription factor families. Among the identified unigenes, the highest of them represented the WD40 family followed by C2H2, MYB-HB, AP2-EREBP, PHD etc. the top 15 have been shown in the table.(Figure 6).

\section{Acknowledgments:}

We are grateful to GBRC (Gujarat Biotechnology Research Centre) for providing the platform for performing the experiment. All the facilities were provided by GBRC including Computational Analysis. The Department of Botany, Faculty of Science, The Maharaja Sayajirao University Baroda for the all the supports for this work.

\section{Author's contribution:}

All authors have contributed to various aspects of this work. PN and MJ conceived the idea and designed the experiments. TM and HZ performed the experiment. TM, HZ, GA and AP analyzed the data. TM analyzed the results and wrote the manuscript. PSN, HZ and MJ finalized the manuscript.

\section{References}

A, W. L., and Godzik, A. (2006). Cd-hit: a fast program for clustering and comparing large sets of protein or nucleotide sequences, 22(13), 1658-1659. https://doi.org/10.1093/bioinformatics/btl158. 
Altschul, S.F., Gish, W., Miller, W., Myers, E.W., Lipman, D.J., 1990. Basic local alignment search tool. Journal of molecular biology 215, 403-410.

Andrews, S. (2010). FastQC: A quality control tool for high throughput sequence data. Available online at: http://www.bioinformatics.babraham.ac.uk/projects/fastqc.

Bains, S., Thakur, V., Kaur, J., Singh, K., \& Kaur, R. (2018). Genomics Elucidating genes involved in sesquiterpenoid and flavonoid biosynthetic pathways in Saussurea lappa by de novo leaf transcriptome analysis. Genomics, 0-1. https://doi.org/10.1016/j.ygeno.2018.09.022.

Beier, S., Thiel, T., Münch, T., Scholz, U., \& Mascher, M. (2017). MISA-web: a web server for microsatellite prediction. Bioinformatics (Oxford, England), 33(16), 25832585. https://doi.org/10.1093/bioinformatics/btx198.

Chen, H., Wang, L., Wang, S., Liu, C., Blair, M. W., \& Cheng, X. (2015). Transcriptome sequencing of mung bean (Vigna radiate L.) genes and the identification of EST-SSR markers. PLoS ONE, 10(4). https://doi.org/10.1371/journal.pone.0120273

Chin, Y. W., Jung, H. A., Liu, Y., Su, B. N., Castoro, J. A., Keller, W. J., ... Kinghorn, A. D. (2007). Anti-oxidant constituents of the roots and stolons of licorice (Glycyrrhiza glabra). Journal of Agricultural and Food Chemistry, 55(12), 4691-4697. https://doi.org/10.1021/jf0703553.

Chirumbolo, S. (2016). Commentary: The antiviral and antimicrobial activities of licorice, a widely-used Chinese herb, 7(April), 1-3. https://doi.org/10.1002/ptr.2295

Chomczynski, P., \& Sacchi, N. (1987). Single-step method of RNA isolation by acid guanidinium thiocyanate-phenol-chloroform extraction. Analytical Biochemistry, 162(1), 156-159. https://doi.org/10.1016/0003-2697(87)90021-2

Conesa, A., Götz, S., García-gómez, J. M., Terol, J., Talón, M., Genómica, D., ... Valencia, U. P. De. (2005). Blast2GO : a universal tool for annotation , visualization and analysis in functional genomics research, 21(18), 3674-3676. https://doi.org/10.1093/bioinformatics/bti610.

Dai, X., Sinharoy, S., Udvardi, M., \& Zhao, P. X. (2013). PlantTFcat: An online plant transcription factor and transcriptional regulator categorization and analysis tool. BMC Bioinformatics, 14(1). https://doi.org/10.1186/1471-2105-14-321.

Dutta, S., Kumawat, G., Singh, B. P., Gupta, D. K., Singh, S., Dogra, V., Singh, N. K. (2011). Development of genic-SSR markers by deep transcriptome sequencing in pigeonpea [ Cajanus cajan ( L .) Millspaugh ]. https://doi.org/10.1186/1471-2229-11-17 
Garg, R., \& Jain, M. (2013). RNA-Seq for transcriptome analysis in non-model plants. Methods in Molecular Biology. https://doi.org/10.1007/978-1-62703-613-9_4

Ghawana, S., Paul, A., Kumar, H., Kumar, A., Singh, H., Bhardwaj, P. Kumar, S. (2011). An RNA isolation system for plant tissues rich in secondary metabolites. BMC Research Notes, 4(1), 85. https://doi.org/10.1186/1756-0500-4-85

Gohil Amit, N., \& Daniel, M. (2014). Development of quality standards of Taverniera cuneifolia (Roth) arn. root - A substitute drug for liquorice. International Journal of Pharmacognosy and Phytochemical Research, 6(2), 255-259.

Gore, R., \& Gaikwad, S. (2015). Checklist of Fabaceae Lindley in Balaghat Ranges of Maharashtra, India. Biodiversity Data Journal, 3, e4541. https://doi.org/10.3897/BDJ.3.e4541

Grabherr, M. G., Haas, B. J., Yassour, M., Levin, J. Z., Thompson, D. A., Amit, I. Regev, A. (2011). Full-length transcriptome assembly from RNA-Seq data without a reference genome, 29(7). https://doi.org/10.1038/nbt.1883

Haas, B. J., Delcher, A. L., Mount, S. M., Wortman, J. R., Jr, R. K. S., Hannick, L. I., White, O. (2003). Improving the Arabidopsis genome annotation using maximal transcript alignment assemblies, 31(19), 5654-5666. https://doi.org/10.1093/nar/gkg770

J. Thaker, Kathiyawadna Bardadungarni jadibuti teni pariksha ane upyog, Gujarati Press Publishers, Mumbai (1910).

Kamboj VP (2000). Herbal Medicine. Current Science, 78, 35-9.

Kanehisa, M., Goto, S., 2000. KEGG: Kyoto encyclopedia of genes and genomes. Nucleic acids research 28, 27-30.

Li, B., Fillmore, N., Bai, Y., Collins, M., Thomson, J. A., Stewart, R., \& Dewey, C. N. (2014). Evaluation of de novo transcriptome assemblies from RNA-Seq data, 1-21. https://doi.org/10.1186/s13059-014-0553-5

Li, H., Fu, Y., Sun, H., Zhang, Y., \& Lan, X. (2017). Transcriptomic analyses reveal biosynthetic genes related to rosmarinic acid in Dracocephalum tanguticum. Scientific Reports, (January), 1-10. https://doi.org/10.1038/s41598-017-00078.

Li, J., Dai, X., Zhuang, Z., \& Zhao, P. X. (2016). LegumeIP 2.0-a platform for the study of gene function and genome evolution in legumes. Nucleic Acids Research, 44(D1), D1189-D1194. https://doi.org/10.1093/nar/gkv1237

Li, Y., Luo, H.-M., Sun, C., Song, J.-Y., Sun, Y.-Z., Wu, Q., Chen, S.-L. (2010). EST analysis reveals putative genes involved in glycyrrhizin biosynthesis. BMC Genomics, 11(268), 268. https://doi.org/10.1186/1471-2164-11-268. 
Liao, Z., Chen, M., Guo, L., Gong, Y., Tang, F., Sun, X., \& Tang, K. (2004). Rapid isolation of high-quality total RNA from taxus and ginkgo. Preparative Biochemistry \& Biotechnology, 34(3), 209-214. https://doi.org/10.1081/PB-200026790

Liu, P. L., Wen, J., Duan, L., Arslan, E., Ertuğrul, K., \& Chang, Z. Y. (2017). Hedysarum L.(Fabaceae: Hedysareae) is not monophyletic-evidence from phylogenetic analyses based on five nuclear and five plastid sequences. PLoS One, 12(1), e0170596.

Liu, Y., Zhang, P., Song, M., Hou, J., Qing, M., Wang, W., \& Liu, C. (2015). Transcriptome analysis and development of SSR molecular markers in Glycyrrhiza uralensis fisch. PLoS ONE, 10(11), 1-12. https://doi.org/10.1371/journal.pone.0143017 Mangalorkar, Bioprospecting the potential of Taverniera cuneifolia Roth Ali. Ph.D Thesis in Department of Botany, Faculty of Science, The Maharaja Sayajirao University of Baroda. Gujarat, India (2016).

Maroufi, A. (2016). Selection of reference genes for real-time quantitative PCR analysis of gene expression in Glycyrrhiza glabra under drought stress. Biologia Plantarum, 60(4). https://doi.org/10.1007/s10535-016-0601-y

Metzker, M. L. (2010). Sequencing technologies - the next generation. Nature Reviews. Genetics, 11(1), 31-46. https://doi.org/10.1038/nrg2626

Mochida, K., Sakurai, T., Seki, H., Yoshida, T., Takahagi, K., Sawai, S., Saito, K. (2017). Draft genome assembly and annotation of Glycyrrhiza uralensis, a medicinal legume. Plant Journal, 89(2), 181-194. https://doi.org/10.1111/tpj.13385

Moriya, Y., Itoh, M., Okuda, S., Yoshizawa, A.C., Kanehisa, M., 2007. KAAS: an automatic genome annotation and pathway reconstruction server. Nucleic acids research 35, W182--W185.

Nadiya, F., Anjali, N., Thomas, J., Gangaprasad, A., \& Sabu, K. K. (2017). Transcriptome profiling of Elettaria cardamomum (L.) Maton (small cardamom). Genomics Data, 11, 102-103. https://doi.org/10.1016/j.gdata.2016.12.013.

Naik, V.N., 1998. Flora of Marathwada (Ranunculaceae to Convolvulaceae). Amrut Prakashan, Aurangabad, India.

P. Sharma, S. Kumar, S. Beriwal, et al., Comparative transcriptome profiling and coexpression network analysis reveals functionally coordinated genes associated with metabolic processes of Andrographis paniculata, Plant Gene (2019). https://doi.org/10.1016/j.plgene.2020.100234

P.S.Nagar, Floristic Biodiversity of Barda Hills and its Surroundings, Scientific Publishers, Jodhpur, India (2005). 
Pagare, Saurabh, Bhatia, M., Tripathi, N., Pagare, Sonal, Bansal, Y.K., 2015. Secondary metabolites of plants and their role: Overview. Current Trends Biotechnology Pharm 9, 293 -304.

Pastorino, G, Cornara, L, Soares, S, Rodrigues, F, Oliveira, MBPP (2018). Liquorice (Glycyrrhiza glabra): A phytochemical and pharmacological review. Phytotherapy Research. 2018; 32: 2323- 2339. https://doi.org/10.1002/ptr.6178.

Perveen, Shaista. \& Khatoon, Surayya. (1989). Chromosome numbers in Papilionaceae from Pakistan. Pakistan J. Bot, 21, 247-251.

Ramilowski, J. A., Sawai, S., Seki, H., Mochida, K., Yoshida, T., Sakurai, T., Daub, C. O. (2013). Glycyrrhiza uralensis transcriptome landscape and study of phytochemicals. Plant and Cell Physiology, 54(5), 697-710. https://doi.org/10.1093/pcp/pct057.

Rasool, S., \& Mohamed, R. (2016). Plant cytochrome P450s: nomenclature and involvement in natural product biosynthesis. Protoplasma. https://doi.org/10.1007/s00709-015-0884-4.

Roskov Y.R., Bisby F.A., Zarucchi J.L., Schrire B.D. \& White R.J. (eds.) ILDIS World Database of Legumes: draft checklist, version 10 [published June 2006, but CD shows November 2005 date]. ILDIS, Reading, UK, 2006 [CD-Rom: ISBN 070491248 1] (also available here at https://ildis.org/LegumeWeb10.01.shtml).

School of graduate studies faculty of science departement of chemistry Bioassay Guided Phytochemical Investigation on Roots of Taverniera Abyssinica ( Dingetegna) By : Mekuriaw Assefa Advisor : Ermias Dagne ( Professor ) July , (2010).

Seki, H., Ohyama, K., Sawai, S., Mizutani, M., Ohnishi, T., Sudo, H., Muranaka, T. (2008). Licorice -amyrin 11-oxidase, a cytochrome P450 with a key role in the biosynthesis of the triterpene sweetener glycyrrhizin. Proceedings of the National Academy of Sciences, 105(37), 14204-14209. https://doi.org/10.1073/pnas.0803876105

Seki, H., Sawai, S., Ohyama, K., Mizutani, M., Ohnishi, T., Sudo, H., Muranaka, T. (2011). Triterpene Functional Genomics in Licorice for Identification of CYP72A154 Involved in the Biosynthesis of Glycyrrhizin. The Plant Cell, 23(11), 4112-4123. https://doi.org/10.1105/tpc.110.082685.

Smýkal, P., von Wettberg, E. J., \& McPhee, K. (2020). Legume genetics and biology: from Mendel's pea to legume genomics.

Stadler, M., Dagne, E., Anke, H., 1994. Nematicidal activity of two phytoalexins form Taverniera abyssynica. Planta Med. 60 (6), 550-552. 
Sudo, H., Seki, H., Sakurai, N., Suzuki, H., Shibata, D., Toyoda, A., Saito, K. (2009). Expressed sequence tags from rhizomes of Glycyrrhiza uralensis. Plant Biotechnology, 26(1), 105-107. https://doi.org/10.5511/plantbiotechnology.26.105

Thiel, T., Michalek, W., Varshney, K., \& Graner, A. (2003). Exploiting EST databases for the development and characterization of gene-derived SSR-markers in barley ( Hordeum vulgare L .), 411-422. https://doi.org/10.1007/s00122-002-1031-0

V.N.Naik, Flora of Marathawada (Ranunculaceae to convolvulaceae), Amrut prakashan, Aurangabad, India (1998).

Varshney, R. K., Graner, A., \& Sorrells, M. E. (2005). Genic microsatellite markers in plants : features and applications, 23(1). https://doi.org/10.1016/j.tibtech.2004.11.005 Varshney, R. K., Song, C., Saxena, R. K., Azam, S., Yu, S., Sharpe, A. G., ... Zhang, G. (2013). Draft genome sequence of chickpea ( Cicer arietinum ) provides a resource for trait improvement. Nature Biotechnology, 31(3), 240-246. https://doi.org/10.1038/nbt.2491

Villa-Ruano, N., Pacheco-Hernández, Y., Lozoya-Gloria, E., Castro-Juárez, C. J., MossoGonzalez, C., \& Ramirez-Garcia, S. A. (2015). Cytochrome P450 from Plants: Platforms for valuable phytopharmaceuticals. Tropical Journal of Pharmaceutical Research. https://doi.org/10.4314/tjpr.v14i4.24

Wolf, J. B. W. (2013). Principles of transcriptome analysis and gene expression quantification: an RNA-seq tutorial, 559-572. https://doi.org/10.1111/1755-0998.12109 Yang, R., Yuan, B., Ma, Y., Wang, L., Liu, C., \& Liu, Y. (2015). HMGR, SQS, $\beta$-AS, and Cytochrome P450 Monooxygenase Genes in Glycyrrhiza uralensis. Chinese Herbal Medicines, 7(4), 290-295. https://doi.org/10.1016/s1674-6384(15)60054-5

Zhang, C., Zhang, B., Vincent, M. S., Zhao, S., \& Quantification, G. (2016). Bioinformatics Tools for RNA-seq Gene and Isoform Quantification Next Generation Sequencing \& Applications, 3(3). https://doi.org/10.4172/2469-9853.1000140

Zhang, Y., Zhang, X., Wang, Y.-H., \& Shen, S.-K. (2017). De Novo Assembly of Transcriptome and Development of Novel EST-SSR Markers in Rhododendron rex Lévl. through Illumina Sequencing. Frontiers in Plant Science, 8(September), 1-12. https://doi.org/10.3389/fpls.2017.01664

Zore, G. B., Winston, U. B., Surwase, B. S., Meshram, N. S., Sangle, V. D., Kulkarni, S. S., \& Mohan Karuppayil, S. (2008). Chemoprofile and bioactivities of Taverniera cuneifolia (Roth) Arn.: A wild relative and possible substitute of Glycyrrhiza glabra L. Phytomedicine, 15(4), 292-300. https://doi.org/10.1016/j.phymed.2007.01.006. 
1 Captions for Tables:

2 Table 1: Summary of sequencing data generated for root sample of Taverniera cuneifolia.

3 Table 2: Results based on combined assembly of Taverniera cuneifolia root transcriptome.

4 Table 3: Identification of Simple Sequence Repeats (SSRs) from Taverniera cuneifolia root

5 transcriptome.

6 Table 4: Candidate "Unigenes" encoding enzymes involved in the Sesquiterpenoid and

7 Triterpenoid biosynthesis, Flavonoid biosynthesis, Terpenoid backbone biosynthesis, Carotenoid

8 biosynthesis, Monoterpenoid biosynthesis and Zeatin biosynthesis identified from Taverniera cuneifolia Transcriptome. 
Table 1: Summary of sequencing data generated for root sample of Taverniera cuneifolia.

\begin{tabular}{|c|l|r|r|}
\hline \multirow{2}{*}{ Sr. No. } & \multicolumn{2}{|c|}{ Features } & \multicolumn{2}{|c|}{ Raw data } \\
\cline { 3 - 4 } & & Sample run 1 & \multicolumn{1}{c|}{ Sample run 2 } \\
\hline 1 & Total reads & $26,652,853$ & $29,338,380$ \\
\hline 2 & Total nucleotides (bp) & $3,604,710,778$ & $3,682,016,643$ \\
\hline 3 & Mean read length (bp) & $135 \mathrm{bp}$ & $126 \mathrm{bp}$ \\
\hline
\end{tabular}

Table 2: Result based on combined assembly of Taverniera cuneifolia root transcriptome.

\begin{tabular}{|c|l|r|}
\hline Sr. No. & Characteristics & Values \\
\hline 1 & Total assembled contigs/transcript & 35,590 \\
\hline 2 & GC \% & 43.25 \\
\hline 3 & Contig N N0 $_{\text {(bp) }}$ & 441 \\
\hline 4 & Median Contig length (bp) & 322 \\
\hline 5 & Average Contig length (bp) & 419.45 \\
\hline 6 & Total assembled bases & $14,928,144$ \\
\hline
\end{tabular}

Table 3: Identification of Simple Sequence Repeats (SSRs) from Taverniera cuneifolia root transcriptome.

\begin{tabular}{|l|r|}
\hline SSR statistics & Count \\
\hline Total number of sequences examined & 35,590 \\
\hline Total size of examined sequences (bp) & $1,49,28,144$ \\
\hline Total number of identified SSRs & 2,912 \\
\hline Number of SSR containing sequences & 2,454 \\
\hline Number of sequences containing more than 1 SSR & 365 \\
\hline Number of SSRs present in compound formation & 265 \\
\hline Mono-nucleotide & 832 \\
\hline Di-nucleotide & 597 \\
\hline Tri-nucleotide & 1291 \\
\hline Tetra-nucleotide & 153 \\
\hline Penta-nucleotide & 33 \\
\hline Hexa-nucleotide & 6 \\
\hline
\end{tabular}

Table 4: Candidate "Unigenes" encoding enzymes involved in the Sesquiterpenoid and Triterpenoid biosynthesis, Flavonoid biosynthesis, Terpenoid backbone biosynthesis, Carotenoid biosynthesis, Monoterpenoid biosynthesis and Zeatin biosynthesis identified from Taverniera cuneifolia Transcriptome.

\begin{tabular}{|l|l|l|l|l|}
\hline Pathway & Name & Description & KO no. & EC no. \\
\hline $\begin{array}{l}\text { Sesquiterpenoid } \\
\text { and Triterpenoid } \\
\text { biosynthesis }\end{array}$ & FDFT1 & $\begin{array}{l}\text { farnesyl-diphosphate } \\
\text { farnesyltransferase }\end{array}$ & ko:K00801 & 2.5 .1 .21 \\
\cline { 2 - 5 } & LUP4 & beta-amyrin synthase & ko:K15813 & 5.4 .99 .39 \\
\cline { 2 - 5 } & PSM & alpha/beta-amyrin synthase & ko:K20658 & 5.4 .99 .40 \\
\hline
\end{tabular}




\begin{tabular}{|c|c|c|c|c|}
\hline & & & & 5.4 .99 .39 \\
\hline $\begin{array}{l}\text { Flavanoid } \\
\text { biosynthesis }\end{array}$ & & $\begin{array}{l}\text { shikimate O- } \\
\text { hydroxycinnamoyltransferase }\end{array}$ & ko:K13065 & 2.3.1.133 \\
\hline \multirow{3}{*}{$\begin{array}{l}\text { Terpenoid } \\
\text { backbone } \\
\text { biosynthesis }\end{array}$} & gсрE & $\begin{array}{l}\text { (E)-4-hydroxy-3-methylbut-2- } \\
\text { enyl-diphosphate synthase }\end{array}$ & ko:K03526 & $\begin{array}{l}1.17 .7 .1 \\
1.17 .7 .3\end{array}$ \\
\hline & SPS & $\begin{array}{l}\text { all-trans-nonaprenyl- } \\
\text { diphosphate synthase }\end{array}$ & ko:K05356 & $\begin{array}{l}2.5 .1 .84 \\
2.5 .1 .85\end{array}$ \\
\hline & PCME & $\begin{array}{l}\text { prenylcysteine alpha-carboxyl } \\
\text { methylesterase }\end{array}$ & ko:K15889 & 3.1.1.-] \\
\hline \multirow{3}{*}{$\begin{array}{l}\text { Carotenoid } \\
\text { biosynthesis }\end{array}$} & AAO3 & abscisic-aldehyde oxidase & ko:K09842 & 1.2.3.14 \\
\hline & CYP707A & $\begin{array}{l}(+) \text {-abscisic acid 8'- } \\
\text { hydroxylase }\end{array}$ & ko:K09843 & 1.14 .14 .137 \\
\hline & AOG & $\begin{array}{l}\text { abscisate beta- } \\
\text { glucosyltransferase }\end{array}$ & ko:K14595 & 2.4 .1 .263 \\
\hline \multirow[t]{2}{*}{$\begin{array}{l}\text { Monoterpenoid } \\
\text { biosynthesis }\end{array}$} & UGT8 & $\begin{array}{l}\text { 7-deoxyloganetic acid } \\
\text { glucosyltransferase }\end{array}$ & ko:K21373 & 2.4.1.323 \\
\hline & UGT85A23_24 & $\begin{array}{l}\text { 7-deoxyloganetin } \\
\text { glucosyltransferase }\end{array}$ & ko:K21374 & 2.4 .1 .324 \\
\hline \multirow[t]{2}{*}{$\begin{array}{l}\text { Zeatin } \\
\text { biosynthesis }\end{array}$} & miaA & $\begin{array}{l}\text { tRNA } \\
\text { dimethylallyltransferase }\end{array}$ & ko:K00791 & 2.5.1.75 \\
\hline & UGT73C & UDP-glucosyltransferase 73C & ko:K13496 & 2.4.1.- \\
\hline
\end{tabular}




\section{Captions for Figures:}

26 Figure 1: Species distribution of the top BLAST hits of Taverniera cuneifolia transcripts in

27 Nr database

28 Figure 2: Biological processes gene ontology of Taverniera cuneifolia transcripts

29 Figure 3: Molecular functions gene ontology of Taverniera cuneifolia transcripts

30 Figure 4: Cellular components gene ontology of Taverniera cuneifolia transcripts

31 Figure 5: Enzyme classification of Taverniera cuneifolia transcripts based on KEGG pathway

32 Figure 6: Top 15 Transcription factors families detection from Taverniera cuneifolia root 33 transcriptome. 
bioRxiv preprint doi: $h$ ttps://doi.org/10.1101/2022.01 27.477879; this version posted January 28,2022 . The copyright holder for this preprint (which was not certified by peer review) is the author/funder, who has granted bioRxiv a license to display the preprint in perpetuity. It is made available under aCC-BY-NC-ND 4.0 International license.

Figure 1: Species distribution of the top BLAST hits of Taverniera cuneifolia transcripts in $\mathrm{Nr}$ database.

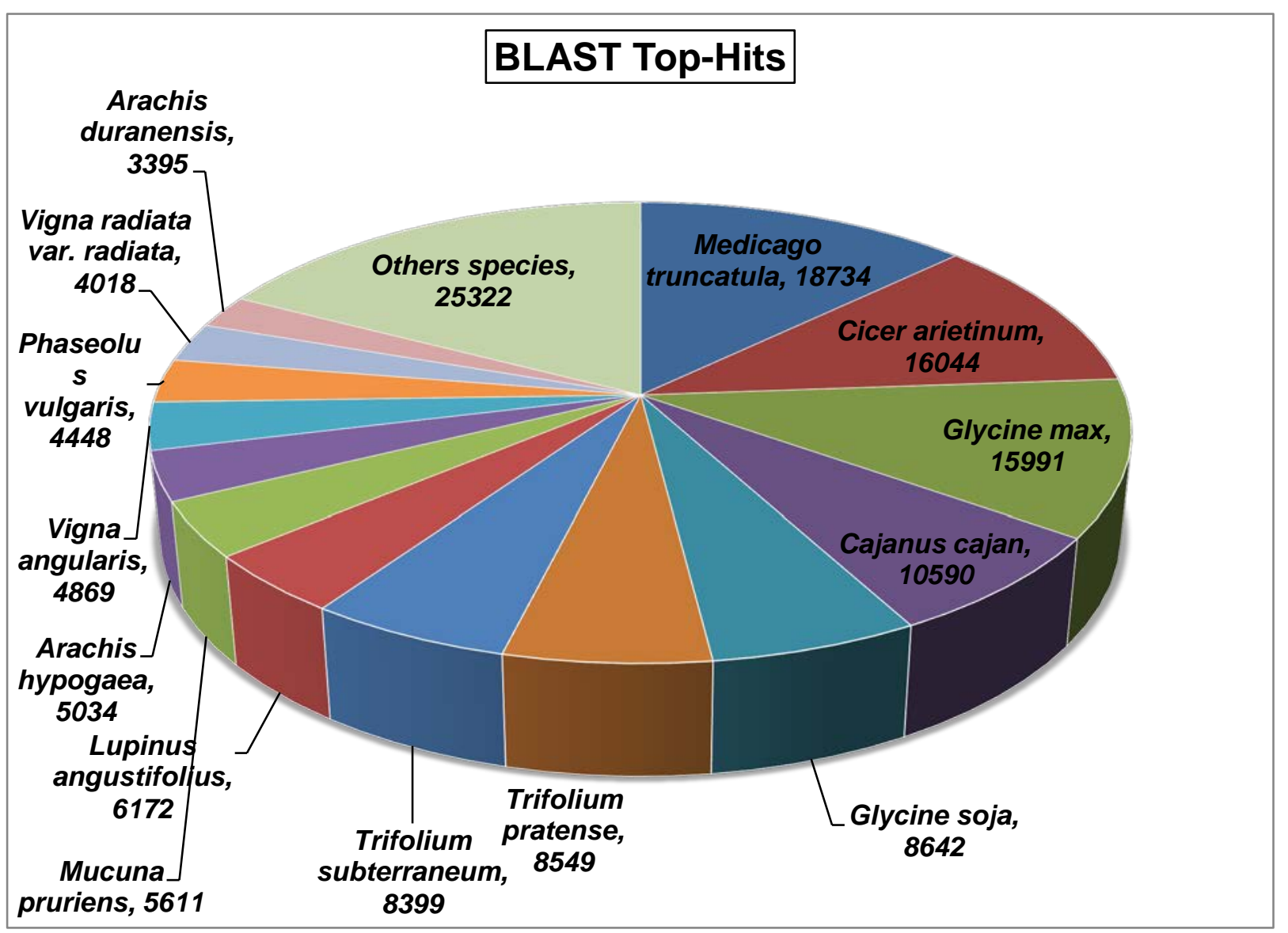


bioRxiv preprint doi: https://doi.org/10.1101/2022.01.27.477879; this version posted January 28, 2022. The copyright holder for this preprint (which was not certified by peer review) is the author/funder, who has granted bioRxiv a license to display the preprint in perpetuity. It is made available under aCC-BY-NC-ND 4.0 International license.

$40 \quad$ Figure 2: Biological processes gene ontology of Taverniera cuneifolia transcripts.

\section{Top 20 Biological processes of Taverniera cuneifolia}

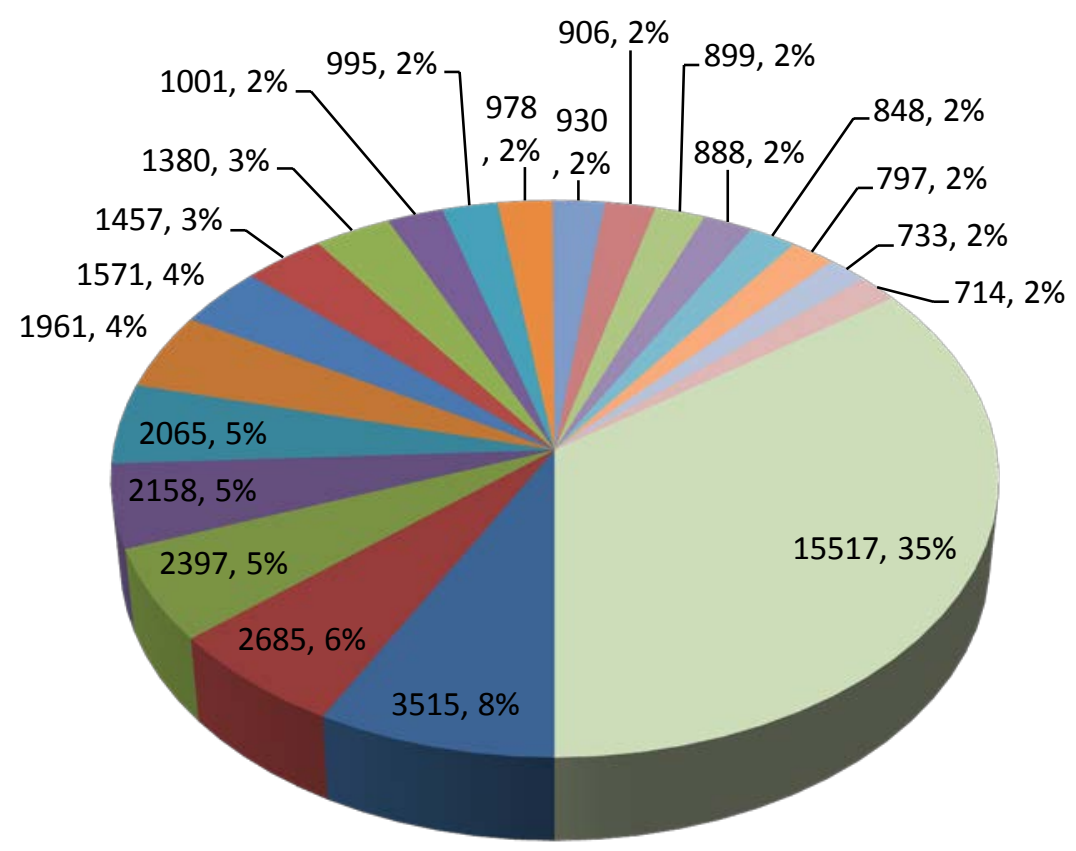

Biological Process

Metabolic Process

Cellular Process

- Organic Substance Metabolic Process

- Primary Metabolic Process

- Cellular Metabolic Process

Macromolecule Metabolic Process

- Single-Organism Process

- Cellular Macromolecule Metabolic Process

Protein Metabolic Process

Nitrogen Compound Metabolic Process

- Single-Organism Metabolic Process

Biosynthetic Process 
bioRxiv preprint doi: https://doi.org/10.1101/2022.01 27.477879; this version posted January 28, 2022. The copyright holder for this preprint (which was not certified by peer review) is the author/funder, who has granted bioRxiv a license to display the preprint in perpetuity. It is made available under aCC-BY-NC-ND 4.0 International license.

41 Figure 3: Molecular functions gene ontology of Taverniera cuneifolia transcripts.

\section{Top 20 Molecular Function of Taverniera cuneifolia}

- Molecular Function

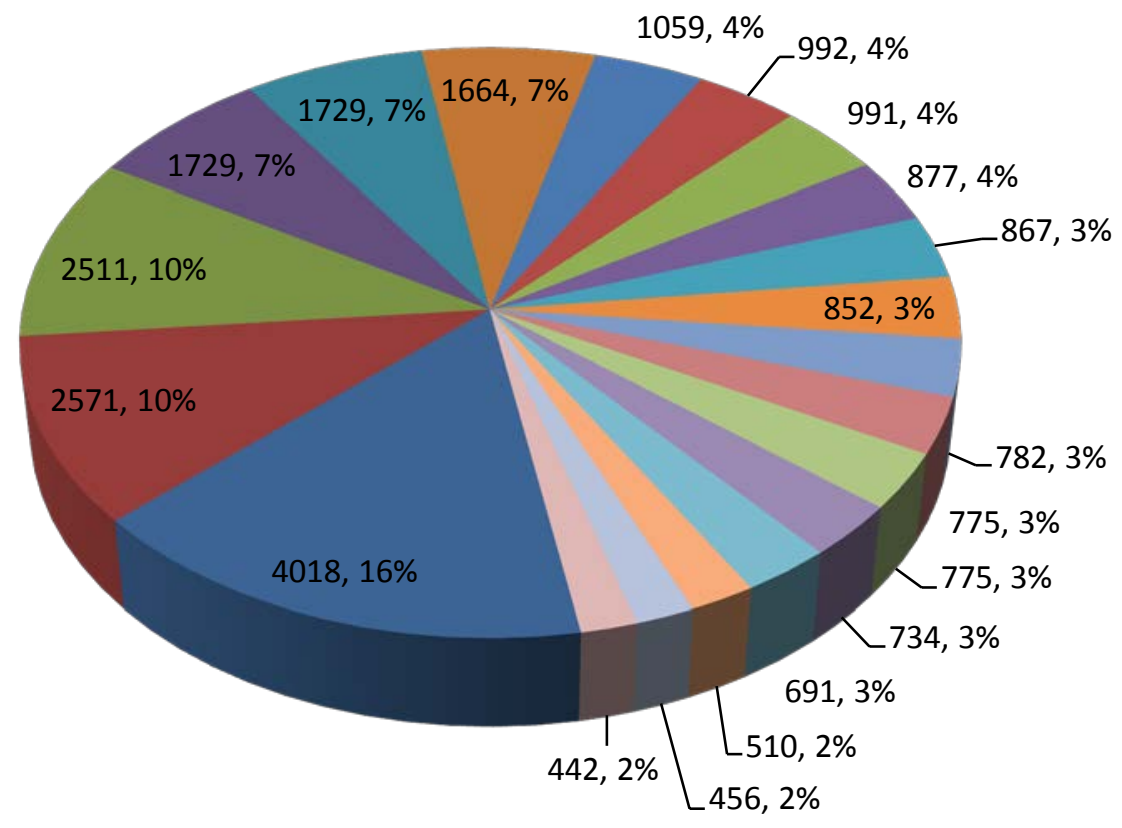

- Catalytic Activity

Binding

Heterocyclic Compound Binding

- Organic Cyclic Compound Binding

lon Binding

nucleotide Binding

Anion Binding

- Transferase Activity 
bioRxiv preprint doi: $h$ ttps://doi.org/10.1101/2022.01.27.477879; this version posted January 28, 2022. The copyright holder for this preprint (which was not certified by peer review) is the author/funder, who has granted bioRxiv a license to display the preprint in perpetuity. It is made available under aCC-BY-NC-ND 4.0 International license.

42 Figure 4: Cellular components gene ontology of Taverniera cuneifolia transcripts.

\section{Top 20 Cellular components of Taverniera cuneifolia}

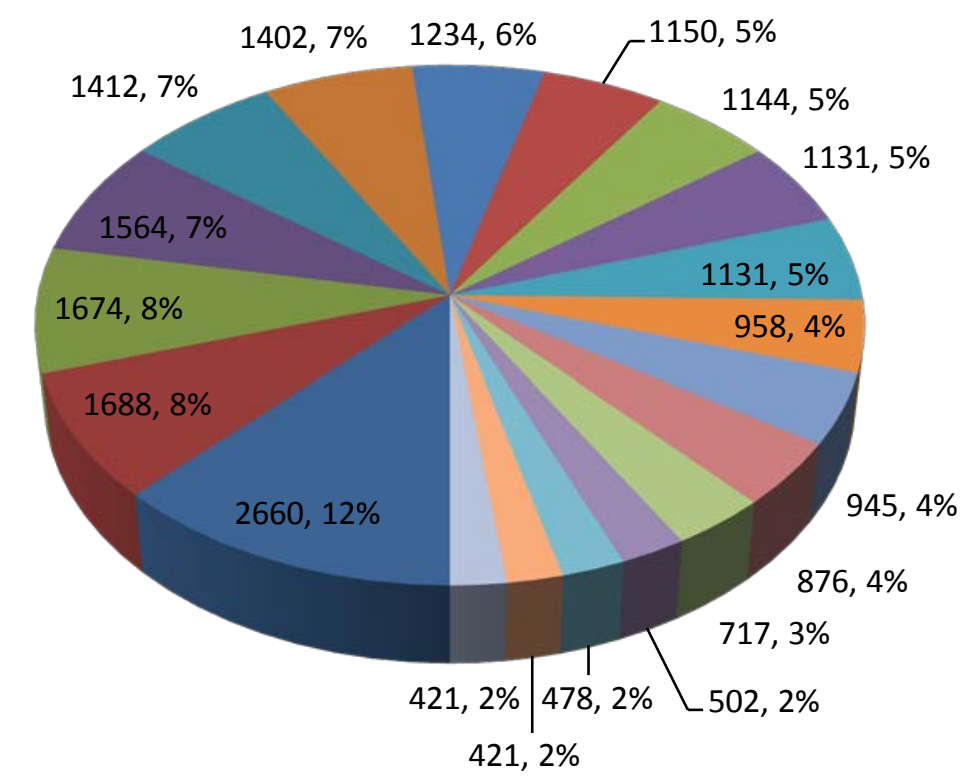

- Cellular Component

- Cell

Cell Part

- Intracellular

- Intracellular Part

Membrane

Membrane Part

- Intrinsic Component Of Membrane

- Integral Component Of

Membrane

arganelle

Intracellular Organelle 
bioRxiv preprint doi: $h$ ttps://doi.org/10.1101/2022.01.27.477879; this version posted January 28, 2022. The copyright holder for this preprint (which was not certified by peer review) is the author/funder, who has granted bioRxiv a license to display the preprint in perpetuity. It is made available under aCC-BY-NC-ND 4.0 International license.

Figure 5: Enzyme classification of Taverniera cuneifolia transcripts based on KEGG pathway.

\section{Enzyme classification}

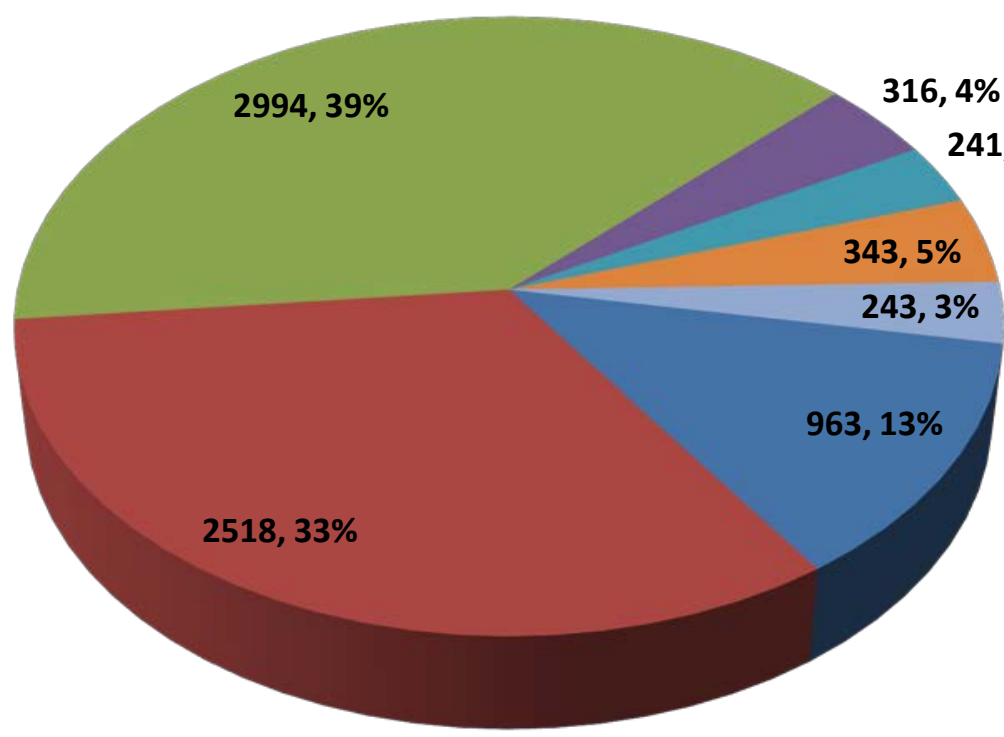

1.- Oxidoreductases

2.- Transferases

3.- Hydrolases

4.- Lyases

5.- Isomerases

6.- Ligases

7.- Translocases 
bioRxiv preprint doi: $\mathrm{https}$ ://doi.org/10.1101/2022.01.27.477879; this version posted January 28, 2022. The copyright holder for this preprint (which was not certified by peer review) is the author/funder, who has granted bioRxiv a license to display the preprint in perpetuity. It is made available under aCC-BY-NC-ND 4.0 International license.

Figure 6: Top 15 Transcription factors families detection from Taverniera cuneifolia root transcriptome.

\section{Transcription factors}

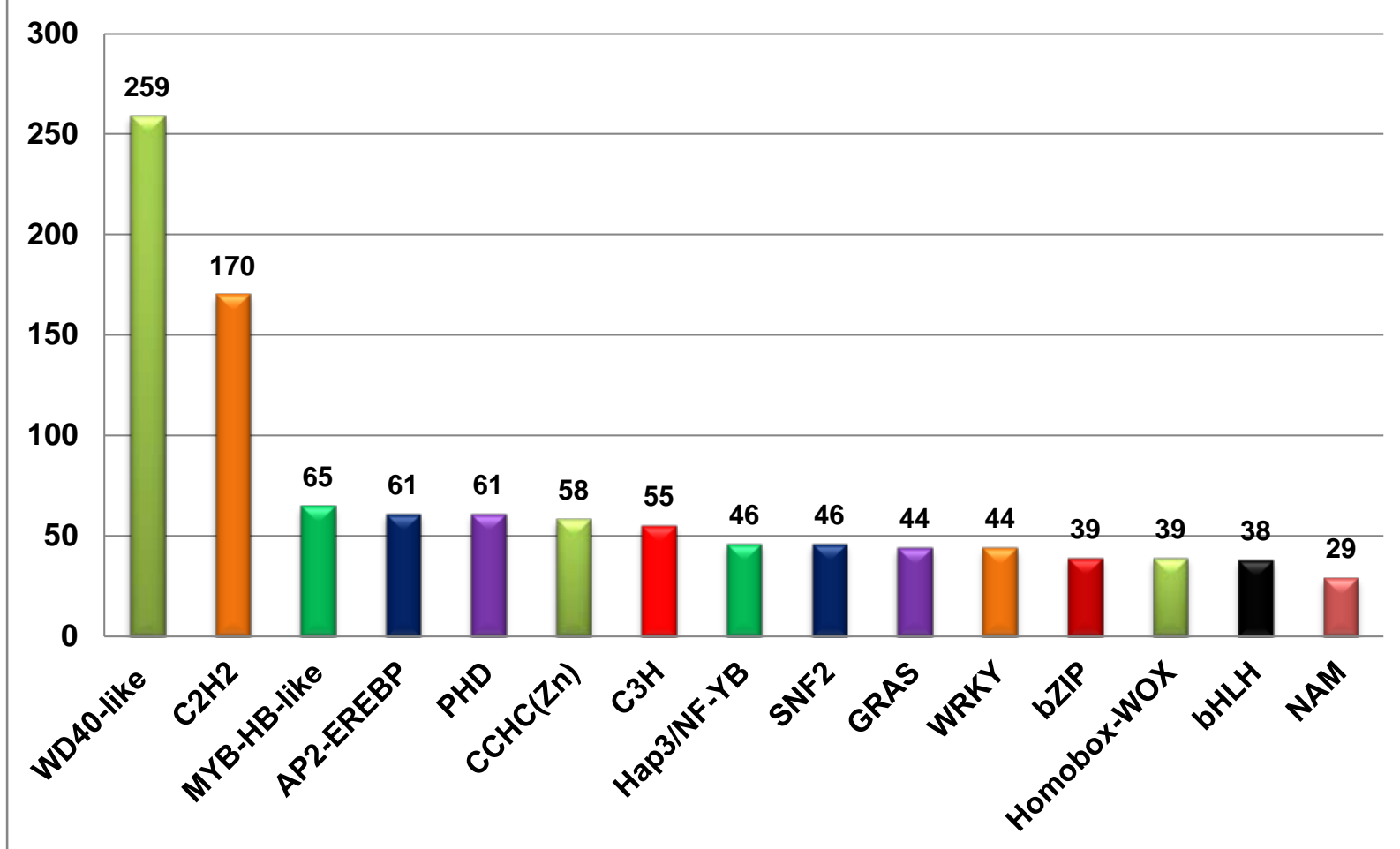


Supplementary Tables:

47 Table S1: GO sequence distribution of biological processes, molecular functions and cellular 48 components.

\begin{tabular}{|c|c|c|}
\hline GO term & Process & $\begin{array}{l}\text { No. of } \\
\text { Transcripts }\end{array}$ \\
\hline \multirow{39}{*}{$\begin{array}{c}\text { Biological } \\
\text { processes } \\
(44,395)\end{array}$} & Biological process & 3515 \\
\hline & Metabolic process & 2685 \\
\hline & Cellular process & 2397 \\
\hline & Organic substance metabolic process & 2158 \\
\hline & Primary metabolic process & 2065 \\
\hline & Cellular metabolic process & 1961 \\
\hline & Macromolecule metabolic process & 1571 \\
\hline & Single-organism process & 1457 \\
\hline & Cellular macromolecule metabolic process & 1380 \\
\hline & Protein metabolic process & 1001 \\
\hline & Nitrogen compound metabolic process & 995 \\
\hline & Single-organism metabolic process & 978 \\
\hline & Biosynthetic process & 930 \\
\hline & Organic substance biosynthetic process & 906 \\
\hline & Cellular nitrogen compound metabolic process & 899 \\
\hline & Cellular biosynthetic process & 888 \\
\hline & Cellular protein metabolic process & 848 \\
\hline & Single-organism cellular process & 797 \\
\hline & Organic cyclic compound metabolic process & 733 \\
\hline & Heterocycle metabolic process & 714 \\
\hline & Cellular aromatic compound metabolic process & 712 \\
\hline & Macromolecule biosynthetic process & 673 \\
\hline & Nucleobase-containing compound metabolic process & 659 \\
\hline & Cellular macromolecule biosynthetic process & 650 \\
\hline & Cellular nitrogen compound biosynthetic process & 637 \\
\hline & Phosphorus metabolic process & 632 \\
\hline & Gene expression & 631 \\
\hline & Phosphate-containing compound metabolic process & 629 \\
\hline & Biological regulation & 614 \\
\hline & Macromolecule modification & 589 \\
\hline & Protein modification process & 576 \\
\hline & Cellular protein modification process & 576 \\
\hline & Regulation of biological process & 555 \\
\hline & Localization & 533 \\
\hline & Nucleic acid metabolic process & 531 \\
\hline & Establishment of localization & 530 \\
\hline & Transport & 529 \\
\hline & Regulation of cellular process & 513 \\
\hline & Organonitrogen compound metabolic process & 493 \\
\hline
\end{tabular}




\begin{tabular}{|c|c|c|}
\hline & Oxidation-reduction process & 483 \\
\hline & Phosphorylation & 478 \\
\hline & RNA metabolic process & 459 \\
\hline & Organic cyclic compound biosynthetic process & 437 \\
\hline & Response to stimulus & 433 \\
\hline & Heterocycle biosynthetic process & 421 \\
\hline & Aromatic compound biosynthetic process & 416 \\
\hline & Small molecule metabolic process & 386 \\
\hline & Nucleobase-containing compound biosynthetic process & 383 \\
\hline & Organonitrogen compound biosynthetic process & 359 \\
\hline \multirow{19}{*}{$\begin{array}{c}\text { Cellular } \\
\text { components } \\
(21,508)\end{array}$} & Cellular component & 2660 \\
\hline & Cell & 1688 \\
\hline & Cell part & 1674 \\
\hline & Intracellular & 1564 \\
\hline & Intracellular part & 1412 \\
\hline & Membrane & 1402 \\
\hline & Membrane part & 1234 \\
\hline & Intrinsic component of membrane & 1150 \\
\hline & Integral component of membrane & 1144 \\
\hline & Organelle & 1131 \\
\hline & Intracellular organelle & 1131 \\
\hline & Membrane-bounded organelle & 958 \\
\hline & Intracellular membrane-bounded organelle & 945 \\
\hline & Cytoplasm & 876 \\
\hline & Cytoplasmic part & 717 \\
\hline & Macromolecular complex & 502 \\
\hline & Nucleus & 478 \\
\hline & Organelle part & 421 \\
\hline & Intracellular organelle part & 421 \\
\hline \multirow{15}{*}{$\begin{array}{l}\text { Molecular } \\
\text { functions } \\
(25,025)\end{array}$} & Molecular function & 4018 \\
\hline & Catalytic activity & 2571 \\
\hline & Binding & 2511 \\
\hline & Heterocyclic compound binding & 1729 \\
\hline & Organic cyclic compound binding & 1729 \\
\hline & Ion binding & 1664 \\
\hline & Nucleotide binding & 1059 \\
\hline & Transferase activity & 991 \\
\hline & Ribonucleoside binding & 877 \\
\hline & Purine ribonucleoside binding & 867 \\
\hline & Hydrolase activity & 852 \\
\hline & Adenyl ribonucleotide binding & 775 \\
\hline & Oxidoreductase activity & 456 \\
\hline & Anion binding & 992 \\
\hline & Cation binding & 782 \\
\hline
\end{tabular}




\begin{tabular}{|l|l|r|}
\hline & ATP binding & $\mathbf{7 3 4}$ \\
\cline { 2 - 3 } & Nucleic acid binding & $\mathbf{6 9 1}$ \\
\cline { 2 - 3 } & Transferase activity, transferring phosphorus-containing groups & $\mathbf{5 1 0}$ \\
\cline { 2 - 3 } & Metal ion binding & $\mathbf{7 7 5}$ \\
\cline { 2 - 3 } & Kinase activity & $\mathbf{4 4 2}$ \\
\hline
\end{tabular}

Table S2: Distribution of transcripts to biological pathways using KEGG specific to plants 51 along with KO-ID.

\begin{tabular}{|c|c|c|}
\hline KO-ID & KEGGS Pathways Distribution & Transcripts no. \\
\hline ko01100 & Metabolic pathways & 102 \\
\hline ko01110 & Biosynthesis of secondary metabolites & 55 \\
\hline ko01120 & Microbial metabolism in diverse environments & 22 \\
\hline ko04075 & Plant hormone signal transduction & 15 \\
\hline ko03040 & Spliceosome & 14 \\
\hline ko01200 & Carbon metabolism & 13 \\
\hline ko03010 & Ribosome & 13 \\
\hline ko04144 & Endocytosis & 13 \\
\hline ko03013 & RNA transport & 12 \\
\hline ko04714 & Thermogenesis & 12 \\
\hline ko04626 & Plant-pathogen interaction & 12 \\
\hline ko04016 & MAPK signaling pathway - plant & 11 \\
\hline ko04120 & Ubiquitin mediated proteolysis & 10 \\
\hline ko04141 & Protein processing in endoplasmic reticulum & 10 \\
\hline ko01230 & Biosynthesis of amino acids & 10 \\
\hline ko00520 & Amino sugar and nucleotide sugar metabolism & 10 \\
\hline ko03018 & RNA degradation & 10 \\
\hline ko00190 & Oxidative phosphorylation & 9 \\
\hline ko03015 & mRNA surveillance pathway & 8 \\
\hline ko00500 & Starch and sucrose metabolism & 7 \\
\hline ko01240 & Biosynthesis of cofactors & 7 \\
\hline ko04146 & Peroxisome & 7 \\
\hline ko00620 & Pyruvate metabolism & 7 \\
\hline ko00010 & Glycolysis / Gluconeogenesis & 6 \\
\hline ko03050 & Proteasome & 5 \\
\hline ko00052 & Galactose metabolism & 5 \\
\hline ko04810 & Regulation of actin cytoskeleton & 5 \\
\hline ko00051 & Fructose and mannose metabolism & 5 \\
\hline ko03008 & Ribosome biogenesis in eukaryotes & 5 \\
\hline ko00270 & Cysteine and methionine metabolism & 5 \\
\hline ko00240 & Pyrimidine metabolism & 5 \\
\hline
\end{tabular}




\begin{tabular}{|c|c|c|}
\hline ko04142 & Lysosome & 5 \\
\hline ko00920 & Sulfur metabolism & 4 \\
\hline ko00410 & beta-Alanine metabolism & 4 \\
\hline ko03420 & Nucleotide excision repair & 4 \\
\hline ko00230 & Purine metabolism & 4 \\
\hline ko00983 & Drug metabolism - other enzymes & 4 \\
\hline ko04110 & Cell cycle & 4 \\
\hline ko00020 & Citrate cycle & 4 \\
\hline ko00970 & Aminoacyl-tRNA biosynthesis & 4 \\
\hline ko04072 & Phospholipase D signaling pathway & 4 \\
\hline ko00250 & Alanine, aspartate and glutamate metabolism & 4 \\
\hline ko00720 & Carbon fixation pathways in prokaryotes & 4 \\
\hline ko00940 & Phenylpropanoid biosynthesis & 4 \\
\hline ko00564 & Glycerophospholipid metabolism & 4 \\
\hline ko00710 & Carbon fixation in photosynthetic organisms & 4 \\
\hline ko00480 & Glutathione metabolism & 4 \\
\hline ko01212 & Fatty acid metabolism & 4 \\
\hline ko00906 & Carotenoid biosynthesis & 3 \\
\hline ko00030 & Pentose phosphate pathway & 3 \\
\hline ko00071 & Fatty acid degradation & 3 \\
\hline ko00280 & Valine, leucine and isoleucine degradation & 3 \\
\hline ko00330 & Arginine and proline metabolism & 3 \\
\hline ko04712 & Circadian rhythm - plant & 3 \\
\hline ko00040 & Pentose and glucuronate interconversions & 3 \\
\hline ko01210 & 2-Oxocarboxylic acid metabolism & 3 \\
\hline ko03020 & RNA polymerase & 3 \\
\hline ko00909 & Sesquiterpenoid and triterpenoid biosynthesis & 3 \\
\hline ko00900 & Terpenoid backbone biosynthesis & 3 \\
\hline ko00460 & Cyanoamino acid metabolism & 2 \\
\hline ko03410 & Base excision repair & 2 \\
\hline ko00902 & Monoterpenoid biosynthesis & 2 \\
\hline ko00340 & Histidine metabolism & 2 \\
\hline ko00908 & Zeatin biosynthesis & 2 \\
\hline ko00980 & Metabolism of xenobiotics by cytochrome P450 & 2 \\
\hline ko03440 & Homologous recombination & 2 \\
\hline ko00061 & Fatty acid biosynthesis & 2 \\
\hline ko00630 & Glyoxylate and dicarboxylate metabolism & 2 \\
\hline ko02010 & ABC transporters & 2 \\
\hline ko01040 & Biosynthesis of unsaturated fatty acids & 2 \\
\hline ko04978 & Mineral absorption & 2 \\
\hline ko04024 & cAMP signaling pathway & 2 \\
\hline
\end{tabular}




\begin{tabular}{|c|c|c|}
\hline ko00592 & alpha-Linolenic acid metabolism & 2 \\
\hline ko00290 & Valine, leucine and isoleucine biosynthesis & 2 \\
\hline ko00260 & Glycine, serine and threonine metabolism & 2 \\
\hline ko00625 & Chloroalkane and chloroalkene degradation & 2 \\
\hline ko00510 & N-Glycan biosynthesis & 2 \\
\hline ko04310 & Wnt signaling pathway & 2 \\
\hline ko04020 & Calcium signaling pathway & 2 \\
\hline ko00310 & Lysine degradation & 2 \\
\hline ko03060 & Protein export & 2 \\
\hline ko04922 & Glucagon signaling pathway & 2 \\
\hline ko00640 & Propanoate metabolism & 2 \\
\hline ko00941 & Flavonoid biosynthesis & 1 \\
\hline ko03430 & Mismatch repair & 1 \\
\hline ko00220 & Arginine biosynthesis & 1 \\
\hline ko02020 & Two-component system & 1 \\
\hline ko00945 & Stilbenoid, diarylheptanoid and gingerol biosynthesis & 1 \\
\hline ko00513 & Various types of N-glycan biosynthesis & 1 \\
\hline ko00903 & Limonene and pinene degradation & 1 \\
\hline ko00966 & Glucosinolate biosynthesis & 1 \\
\hline ko00730 & Thiamine metabolism & 1 \\
\hline ko00400 & Phenylalanine, tyrosine and tryptophan biosynthesis & 1 \\
\hline ko04122 & Sulfur relay system & 1 \\
\hline ko00100 & Steroid biosynthesis & 1 \\
\hline ko00380 & Tryptophan metabolism & 1 \\
\hline ko00982 & Drug metabolism - cytochrome P450 & 1 \\
\hline ko00790 & Folate biosynthesis & 1 \\
\hline ko03030 & DNA replication & 1 \\
\hline ko04979 & Cholesterol metabolism & 1 \\
\hline ko00904 & Diterpenoid biosynthesis & 1 \\
\hline ko03022 & Basal transcription factors & 1 \\
\hline ko00130 & Ubiquinone and other terpenoid-quinone biosynthesis & 1 \\
\hline
\end{tabular}




\begin{tabular}{|c|c|c|}
\hline $\begin{array}{l}\text { Sr. } \\
\text { No. }\end{array}$ & Transcript ID & $\begin{array}{l}\text { Best hit Transcripts associated with Glycyrrhizin } \\
\text { biosynthesis pathway from Nr database }\end{array}$ \\
\hline \multicolumn{3}{|c|}{ GENE 1 Squalene synthase/ epoxidase/monooxygenase } \\
\hline 1 & TRINITY_DN11206_c0_g1_i1 & ADG36709.1| squalene synthase 1 \\
\hline 2 & TRINITY_DN11206_c0_g1_i2 & ADG36709.1| squalene synthase 1 \\
\hline 3 & TRINITY_DN25523_c0_g1_i1 & XP_007041440.1 squalene monooxygenase \\
\hline 4 & TRINITY_DN7116_c0_g1_i1 & ADG36706.1squalene synthase 1 \\
\hline 5 & TRINITY_DN9998_c0_g1_i1 & ADG36711.1squalene synthase 1 \\
\hline 6 & TRINITY_DN9998_c0_g1_i2 & CAJ77652.1squalene synthase 1 \\
\hline 7 & TRINITY_DN9998_c0_g1_i3 & ADG36699.1squalene synthase 1 \\
\hline 8 & TRINITY_DN5897_c0_g1_i1 & AHY94896.1squalene epoxidase \\
\hline 9 & TRINITY_DN10863_c0_g1_i1 & AKO83630.1squalene epoxidase \\
\hline 10 & TRINITY_DN14273_c0_g1_i2 & AHY94896.1squalene epoxidase \\
\hline 11 & TRINITY_DN14273_c1_g1_i1 & KEH39980.1squalene monooxygenase \\
\hline 12 & TRINITY_DN3414_c0_g1_i1 & APA19297.1squalene synthase \\
\hline 13 & TRINITY_DN10934_c0_g1_i2 & XP_004498941.1 squalene monooxygenase-like \\
\hline 14 & TRINITY_DN10934_c0_g1_i3 & AKO83630.1squalene epoxidase \\
\hline 15 & TRINITY_DN10934_c0_g1_i4 & AKO83630.1squalene epoxidase \\
\hline \multicolumn{3}{|c|}{ GENE 2 Beta-amyrin synthase } \\
\hline 1 & TRINITY_DN11239_c0_g1_i0031 & AAO33578.1beta-amyrin synthase \\
\hline 2 & TRINITY_DN11239_c0_g1_i2 & NP_001236591.2beta-amyrin synthase \\
\hline 3 & TRINITY_DN28103_c0_g1_i1 & XP_018838319.1 beta-amyrin synthase \\
\hline 4 & TRINITY_DN11371_c0_g1_i1 & NP_001236591.2 beta-amyrin synthase \\
\hline 5 & TRINITY_DN11371_c0_g1_i2 & AHI17180.1 beta-amyrin synthase \\
\hline \multicolumn{3}{|c|}{ GENE 3 Beta-amyrin 11-oxidase /CYP88D6 } \\
\hline 1 & TRINITY_DN20252_c0_g1_i1 & $\begin{array}{l}\text { B5BSX1.1 Full=Beta-amyrin 11-oxidase; AltName: } \\
\text { Full=Cytochrome P450 88D6 }\end{array}$ \\
\hline 2 & TRINITY_DN11652_c0_g1_i3 & $\begin{array}{l}\text { B5BSX1.1 Full=Beta-amyrin 11-oxidase; AltName: } \\
\text { Full=Cytochrome P450 88D6 }\end{array}$ \\
\hline 3 & TRINITY_DN11652_c0_g1_i4 & AQQ13664.1 beta-amyrin 11-oxidase \\
\hline 4 & TRINITY_DN11652_c0_g1_i6 & XP_004510262.1 beta-amyrin 11-oxidase-like \\
\hline \multicolumn{3}{|c|}{ GENE 4 11-oxo-beta-amyrin 30-oxidase/CYP72A154 } \\
\hline 1 & TRINITY_DN5998_c0_g1_i1 & XP_004488667.1 11-oxo-beta-amyrin 30-oxidase-like \\
\hline 2 & TRINITY_DN11613_c0_g1_i1 & $\begin{array}{lll}\text { H1A988.1 } & \text { Full=11-oxo-beta-amyrin } & \text { 30-oxidase; } \\
\text { AltName: Full=Cytochrome P450 72A154 } & \end{array}$ \\
\hline 3 & TRINITY_DN11613_c0_g1_i2 & XP_004511068.1 11-oxo-beta-amyrin 30-oxidase-like \\
\hline 4 & TRINITY_DN11613_c0_g1_i7 & XP_004511068.1 11-oxo-beta-amyrin 30-oxidase-like \\
\hline 5 & TRINITY_DN11613_c0_g1_i9 & XP_004511068.1 11-oxo-beta-amyrin 30-oxidase-like \\
\hline 6 & TRINITY_DN9161_c0_g1_i1 & RHN74756.1putative 11-oxo-beta-amyrin 30-oxidase \\
\hline 7 & TRINITY_DN10411_c0_g1_i2 & XP_004511068.1 11-oxo-beta-amyrin 30-oxidase-like \\
\hline 8 & TRINITY_DN10411_c0_g1_i3 & XP_004511068.1 11-oxo-beta-amyrin 30-oxidase-like \\
\hline 9 & TRINITY_DN10411_c0_g1_i4 & XP_004511068.1 11-oxo-beta-amyrin 30-oxidase-like \\
\hline 10 & TRINITY_DN5730_c0_g1_i1 & XP_004488667.1 11-oxo-beta-amyrin 30-oxidase-like \\
\hline \multicolumn{3}{|c|}{ GENE 5 Beta-amyrin 24-hydroxylase /CYP93E7 } \\
\hline 1 & TRINITY_DN11492_c0_g1_i1 & nyrin 24-hydroxylase CYP93E7 \\
\hline \multicolumn{3}{|c|}{ GENE 6 UDP-glycosyltransferase family protein } \\
\hline 1 & TRINITY_DN25514_c0_g1_i1 & $\begin{array}{l}\text { RHN51110.1putative UDP-glucuronosyl/UDP- } \\
\text { glucosyltransferase }\end{array}$ \\
\hline 2 & TRINITY_DN11708_c3_g1_i1 & XP_022880903.1UDP-glycosyltransferase 73B5-like \\
\hline 3 & TRINITY_DN1272_c0_g1_i1 & AMQ26133.1UDP-glycosyltransferase 3 \\
\hline
\end{tabular}


bioRxiv preprint doi: https://doi.org/101101/2022.01.27.477879; this version posted January 28,2022 . The copyright holder for this preprint (which was not certified by peer review) is the author/funder, who has granted bioRxiv a license to display the preprint in perpetuity. It is made available under aCC-BY-NC-ND 4.0 International license.

\begin{tabular}{|c|c|c|}
\hline 4 & TRINITY_DN14507_c0_g1_i1 & KEH43353.1 UDP-glycosyltransferase family protein \\
\hline 5 & TRINITY_DN7469_c0_g1_i1 & XP_013451680.1UDP-glycosyltransferase 1 \\
\hline 6 & TRINITY_DN30090_c0_g1_i1 & XP_019428832.1 UDP-glycosyltransferase 73C6-like \\
\hline 7 & TRINITY_DN17733_c0_g1_i1 & $\begin{array}{l}\text { XP_003600815.1UDP-glycosyltransferase 76B1 isoform } \\
\text { X1 }\end{array}$ \\
\hline 8 & TRINITY_DN18323_c0_g1_i1 & $\begin{array}{l}\text { XP_012568016.1 UDP-glucose:glycoprotein } \\
\text { glucosyltransferase }\end{array}$ \\
\hline 9 & TRINITY_DN1735_c0_g1_i1 & XP_004489724.1 UDP-glycosyltransferase 74E1 \\
\hline 10 & TRINITY_DN1735_c0_g1_i2 & XP_004489724.1 UDP-glycosyltransferase 74E1 \\
\hline 11 & TRINITY_DN19316_c0_g1_i1 & XP_020228882.1UDP-glycosyltransferase 87A1-like \\
\hline 12 & TRINITY_DN10035_c0_g1_i1 & RDX79205.1UDP-glycosyltransferase 71K2 \\
\hline 13 & TRINITY_DN6951_c0_g1_i1 & XP_004490590.1 UDP-glycosyltransferase 71D1-like \\
\hline 14 & TRINITY_DN12074_c0_g1_i1 & KEH43353.1 UDP-glycosyltransferase family protein \\
\hline 15 & TRINITY_DN27452_c0_g1_i1 & AES66918.2UDP-glucosyltransferase family protein \\
\hline 16 & TRINITY_DN16244_c0_g1_i1 & $\begin{array}{l}\text { XP_012568016.1 UDP-glucose:glycoprotein } \\
\text { glucosyltransferase }\end{array}$ \\
\hline 17 & TRINITY_DN21948_c0_g1_i1 & PNY11551.1UDP-glycosyltransferase-like protein \\
\hline 18 & TRINITY_DN29071_c0_g1_i1 & RDX76823.1UDP-glycosyltransferase 72B1 \\
\hline 19 & TRINITY_DN14490_c0_g1_i1 & XP_014489827.1UDP-glycosyltransferase 87A1 \\
\hline 20 & TRINITY_DN14236_c0_g1_i1 & XP_012568460.1 UDP-glycosyltransferase 87A1-like \\
\hline 21 & TRINITY_DN14292_c0_g1_i1 & PNY09424.1UDP-glycosyltransferase 76F1-like protein \\
\hline 22 & TRINITY_DN23324_c0_g1_i1 & PNY15296.1UDP-glycosyltransferase 87A1-like protein \\
\hline 23 & TRINITY_DN28174_c0_g1_i1 & XP_013451922.1UDP-glycosyltransferase 74G1 \\
\hline 24 & TRINITY_DN29171_c0_g1_i1 & XP_004490654.1 UDP-glycosyltransferase 87A1 \\
\hline 25 & TRINITY_DN16300_c0_g1_i1 & KHN41573.1UDP-glycosyltransferase 83A1 \\
\hline 26 & TRINITY_DN14033_c0_g1_i1 & XP_003544901.1UDP-glycosyltransferase 87A1 \\
\hline 27 & TRINITY_DN22391_c0_g1_i1 & $\begin{array}{l}\text { XP_003599976.1putative UDP-glucose } \\
\text { glucosyltransferase }\end{array}$ \\
\hline 28 & TRINITY_DN9589_c0_g1_i1 & XP_013451680.1UDP-glycosyltransferase 1 \\
\hline 29 & TRINITY_DN9589_c1_g1_i1 & XP_014515686.1UDP-glycosyltransferase 1-like \\
\hline 30 & TRINITY_DN20336_c0_g1_i1 & $\begin{array}{l}\text { XP_004503216.1 UDP-glycosyltransferase 76F1-like } \\
\text { isoform X1 }\end{array}$ \\
\hline 31 & TRINITY_DN17416_c0_g1_i1 & $\begin{array}{l}\text { XP_012568016.1 UDP-glucose:glycoprotein } \\
\text { glucosyltransferase }\end{array}$ \\
\hline 32 & TRINITY_DN29577_c0_g1_i1 & $\begin{array}{l}\text { XP_020240106.1UDP-glycosyltransferase 71K1 isoform } \\
\text { X1 }\end{array}$ \\
\hline
\end{tabular}




\begin{tabular}{|c|c|c|}
\hline $\begin{array}{l}\text { Sr. } \\
\text { No. }\end{array}$ & Transcript ID & $\begin{array}{l}\text { Transcripts associated with Glycyrrhizin biosynthesis } \\
\text { pathway }\end{array}$ \\
\hline 1 & TRINITY_DN11292_c0_g1_i3 & $\begin{array}{l}\text { gi|593801532|ref|XP_007163803.1| hypothetical } \\
\text { protein PHAVU_001G265500g }\end{array}$ \\
\hline 2 & TRINITY_DN11286_c0_g1_i4 & $\begin{array}{l}\text { gi|593795660|ref|XP_007160868.1| hypothetical } \\
\text { protein PHAVU_001G023500g }\end{array}$ \\
\hline 3 & TRINITY_DN10387_c0_g1_i1 & $\begin{array}{l}\text { gi|965601928|dbj|BAT89106.1| hypothetical protein } \\
\text { VIGAN_05279900 }\end{array}$ \\
\hline 4 & TRINITY_DN10679_c0_g1_i1 & $\begin{array}{l}\text { gi|920709256|gb|KOM51253.1| hypothetical protein } \\
\text { LR48_Vigan08g208000 }\end{array}$ \\
\hline 5 & TRINITY_DN11770_c6_g1_i1 & $\begin{array}{l}\text { gi|920715088 |gb|KOM55176.1| hypothetical protein } \\
\text { LR48_Vigan10g106800 }\end{array}$ \\
\hline 6 & TRINITY_DN11705_c1_g1_i3 & $\begin{array}{l}\text { gi|593797882 |ref|XP_007161979.1| hypothetical } \\
\text { protein PHAVU_001G113800g }\end{array}$ \\
\hline 7 & TRINITY_DN11740_c0_g1_i2 & $\begin{array}{l}\text { gi|147782060|emb|CAN61004.1| hypothetical protein } \\
\text { VITISV_015023 }\end{array}$ \\
\hline 8 & TRINITY_DN6658_c0_g1_i1 & $\begin{array}{l}\text { gi|920703423 |gb|KOM46648.1| hypothetical protein } \\
\text { LR48_Vigan07g035200 }\end{array}$ \\
\hline 9 & TRINITY_DN6650_c0_g1_i1 & $\begin{array}{l}\text { gi|965663984|dbj|BAT79693.1| hypothetical protein } \\
\text { VIGAN_02261400 }\end{array}$ \\
\hline 10 & TRINITY_DN11563_c0_g1_i4 & $\begin{array}{l}\text { gi|593701389|ref|XP_007151112.1| hypothetical } \\
\text { protein PHAVU_004G018900g }\end{array}$ \\
\hline 11 & TRINITY_DN11531_c0_g1_i1 & $\begin{array}{l}\text { gi|593700643|ref|XP_007150760.1| hypothetical } \\
\text { protein PHAVU_005G178600g }\end{array}$ \\
\hline 12 & TRINITY_DN11540_c0_g1_i2 & $\begin{array}{l}\text { gi|147781743|emb|CAN61179.1| hypothetical protein } \\
\text { VITISV_032292 }\end{array}$ \\
\hline 13 & TRINITY_DN11053_c1_g1_i2 & $\begin{array}{l}\text { gi|357441957|ref|XP_003591256.1| hypothetical } \\
\text { protein MTR_1g084990 }\end{array}$ \\
\hline 14 & TRINITY_DN11043_c0_g1_i2 & $\begin{array}{l}\text { gi|763758066 |gb|KJB25397.1| hypothetical protein } \\
\text { B456_004G189700 }\end{array}$ \\
\hline 15 & TRINITY_DN11043_c0_g1_i4 & $\begin{array}{l}\text { gi|763758066 |gb|KJB25397.1| hypothetical protein } \\
\text { B456_004G189700 }\end{array}$ \\
\hline 16 & TRINITY_DN11647_c0_g1_i2 & $\begin{array}{l}\text { gi|965604026|dbj|BAT91203.1| hypothetical protein } \\
\text { VIGAN_06251600 }\end{array}$ \\
\hline 17 & TRINITY_DN11647_c0_g1_i5 & $\begin{array}{l}\text { gi|965604026|dbj|BAT91203.1| hypothetical protein } \\
\text { VIGAN_06251600 }\end{array}$ \\
\hline 18 & TRINITY_DN11626_c1_g1_i1 & $\begin{array}{l}\text { gi|593612647|ref|XP_007142864.1| hypothetical } \\
\text { protein PHAVU_007G023200g }\end{array}$ \\
\hline 19 & TRINITY_DN11665_c3_g1_i2 & $\begin{array}{l}\text { gi|947109915|gb|KRH58241.1| hypothetical protein } \\
\text { GLYMA_05G114900 }\end{array}$ \\
\hline 20 & TRINITY_DN11468_c0_g1_i2 & $\begin{array}{l}\text { gi|593799252|ref|XP_007162664.1| hypothetical } \\
\text { protein PHAVU_001G169900g }\end{array}$ \\
\hline 21 & TRINITY_DN11472_c0_g2_i1 & $\begin{array}{l}\text { gi|920703664|gb|KOM46889.1| hypothetical protein } \\
\text { LR48_Vigan07g059300 }\end{array}$ \\
\hline 22 & TRINITY_DN11487_c0_g1_i3 & $\begin{array}{l}\text { gi|947099253 |gb|KRH47745.1| hypothetical protein } \\
\text { GLYMA_07G047800 }\end{array}$ \\
\hline 23 & TRINITY_DN11430_c1_g2_i1 & $\begin{array}{l}\text { gi|593704437|ref|XP_007152592.1| hypothetical } \\
\text { protein PHAVU_004G142900g }\end{array}$ \\
\hline
\end{tabular}




\begin{tabular}{|c|c|c|}
\hline 24 & TRINITY_DN11430_c1_g2_i4 & $\begin{array}{l}\text { gi|593704437|ref|XP_007152592.1| hypothetical } \\
\text { protein PHAVU_004G142900g }\end{array}$ \\
\hline 25 & TRINITY_DN10796_c0_g1_i3 & $\begin{array}{l}\text { gi|965661959|dbj|BAT77668.1| hypothetical protein } \\
\text { VIGAN_02025800 }\end{array}$ \\
\hline 26 & TRINITY_DN4344_c0_g1_i1 & $\begin{array}{l}\text { gi|593694898|ref|XP_007147954.1| hypothetical } \\
\text { protein PHAVU_006G168300g }\end{array}$ \\
\hline 27 & TRINITY_DN11312_c0_g1_i2 & $\begin{array}{l}\text { gi|922399741|ref|XP_013467009.1| hypothetical } \\
\text { protein MTR_1g041275 }\end{array}$ \\
\hline 28 & TRINITY_DN11307_c0_g1_i4 & $\begin{array}{l}\text { gi|920679711|gb|KOM26600.1| hypothetical protein } \\
\text { LR48_Vigan303s002200 }\end{array}$ \\
\hline 29 & TRINITY_DN10957_c0_g1_i3 & $\begin{array}{l}\text { gi|920681762 |gb|KOM28542.1| hypothetical protein } \\
\text { LR48_Vigan549s009700 }\end{array}$ \\
\hline 30 & TRINITY_DN11114_c0_g1_i2 & $\begin{array}{l}\text { gi|357466213|ref|XP_003603391.1| hypothetical } \\
\text { protein MTR_3g107090 }\end{array}$ \\
\hline
\end{tabular}




\begin{tabular}{|l|l|lll|}
\hline $\begin{array}{l}\text { Sr. } \\
\text { No. }\end{array}$ & Transcript ID & $\begin{array}{l}\text { Transcripts associated with Cytochrome P450 family } \\
\text { protein }\end{array}$ & \\
\hline 1 & TRINITY_DN10399_c0_g1_i2 & $\begin{array}{l}\text { gi|356515730|ref|XP_003526551.1| } \\
\text { NADPH--cytochrome P450 reductase }\end{array}$ & PREDICTED: \\
\hline 2 & TRINITY_DN11569_c1_g1_i1 & $\begin{array}{l}\text { gi|357514033|ref|XP_003627305.1| } \\
\text { family monooxygenase }\end{array}$ & cytochromer & P450 \\
\hline 3 & TRINITY_DN11569_c1_g1_i3 & $\begin{array}{l}\text { gi|357514033|ref|XP_003627305.1| } \\
\text { family monooxygenase }\end{array}$ & cytochromec & P450 \\
\hline 4 & TRINITY_DN1922_c0_g1_i2 & $\begin{array}{l}\text { gi|502156756|ref|XP_004510631.1| } \\
\text { cytochrome P450 78A3 }\end{array}$ & PREDICTED: \\
\hline 5 & TRINITY_DN11093_c0_g1_i2 & $\begin{array}{l}\text { gi|922394449|ref|XP_013465628.1| } \\
\text { family Ent-kaurenoic acid oxidase }\end{array}$ & cytochrome & P450 \\
\hline 6 & TRINITY_DN11010_c1_g1_i1 & $\begin{array}{l}\text { gi|357470373|ref|XP_003605471.1| } \\
\text { family monooxygenase }\end{array}$ & cytochrome & P450 \\
\hline 7 & TRINITY_DN11652_c0_g1_i4 & gi|838228579|gb|AKM97308.1| cytochrome P450 88D6 \\
\hline 8 & TRINITY_DN8146_c0_g1_i1 & $\begin{array}{l}\text { gi|371940464|dbj|BAL45206.1| } \\
\text { monooxygenase }\end{array}$ & cytochrome & P450 \\
\hline 9 & TRINITY_DN9931_c0_g1_i2 & $\begin{array}{l}\text { gi|502150242|ref|XP_004507858.1| } \\
\text { NADPH--cytochrome P450 reductase }\end{array}$ & PREDICTED: \\
\hline 10 & TRINITY_DN9161_c0_g1_i1 & $\begin{array}{l}\text { gi|922392052|ref|XP_013464437.1| } \\
\text { family protein }\end{array}$ & cytochrome & P450 \\
\hline 11 & TRINITY_DN3071_c0_g1_i1 & $\begin{array}{l}\text { gi|922399435|ref|XP_013466867.1| } \\
\text { family protein }\end{array}$ & cytochrome & P450 \\
\hline 12 & TRINITY_DN5499_c0_g1_i1 & $\begin{array}{l}\text { gi|922394449|ref|XP_013465628.1| } \\
\text { family Ent-kaurenoic acid oxidase }\end{array}$ & cytochrome & P450 \\
\hline 13 & TRINITY_DN2780_c0_g1_i1 & $\begin{array}{l}\text { gi|502161259|ref|XP_004512097.1| } \\
\text { cytochrome P450 84A1 }\end{array}$ & PREDICTED: \\
\hline 14 & TRINITY_DN2767_c0_g1_i1 & $\begin{array}{l}\text { gi|356569428|ref|XP_003552903.1| } \\
\text { cytochrome P450 714C2-like }\end{array}$ & PREDICTED: \\
\hline 15 & TRINITY_DN10453_c0_g1_i1 & $\begin{array}{l}\text { gi|356540462|ref|XP_003538708.1| } \\
\text { cytochrome P450 87A3-like }\end{array}$ & PREDICTED: \\
\hline 16 & TRINITY_DN10993_c0_g1_i1 & $\begin{array}{l}\text { gi|922380457|ref|XP_013460458.1| } \\
\text { family protein }\end{array}$ & cytochrome & P450 \\
\hline 17 & TRINITY_DN11158_c1_g1_i4 & $\begin{array}{l}\text { gi|922327835|ref|XP_013443310.1| } \\
\text { family 71 protein }\end{array}$ & cytochrome & P450 \\
\hline
\end{tabular}


67 Supplementary Figures:

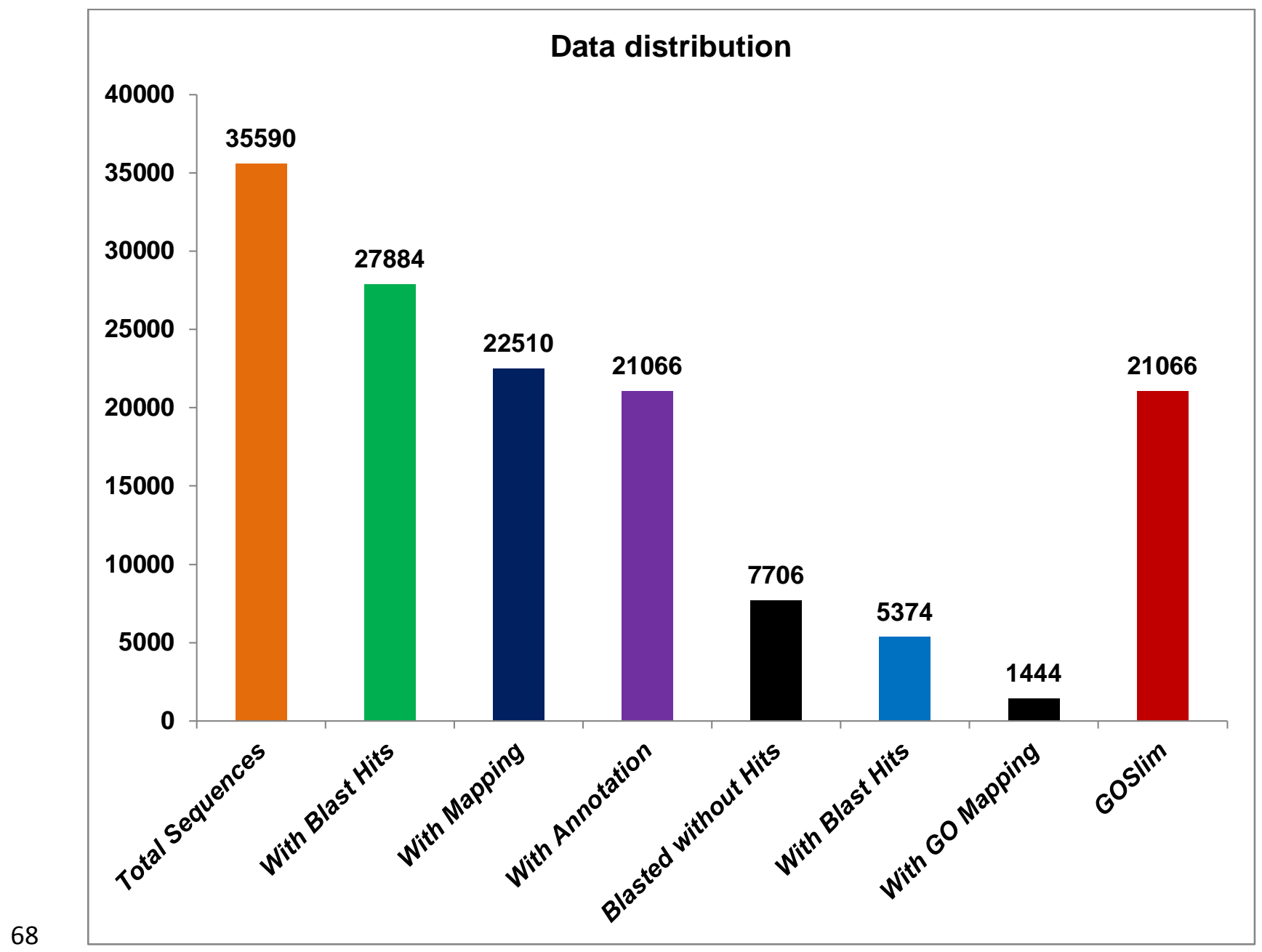

69 Supplementary Fig. S1: Data distribution of Taverniera cuneifolia transcripts subjected to 70 functional annotation. 


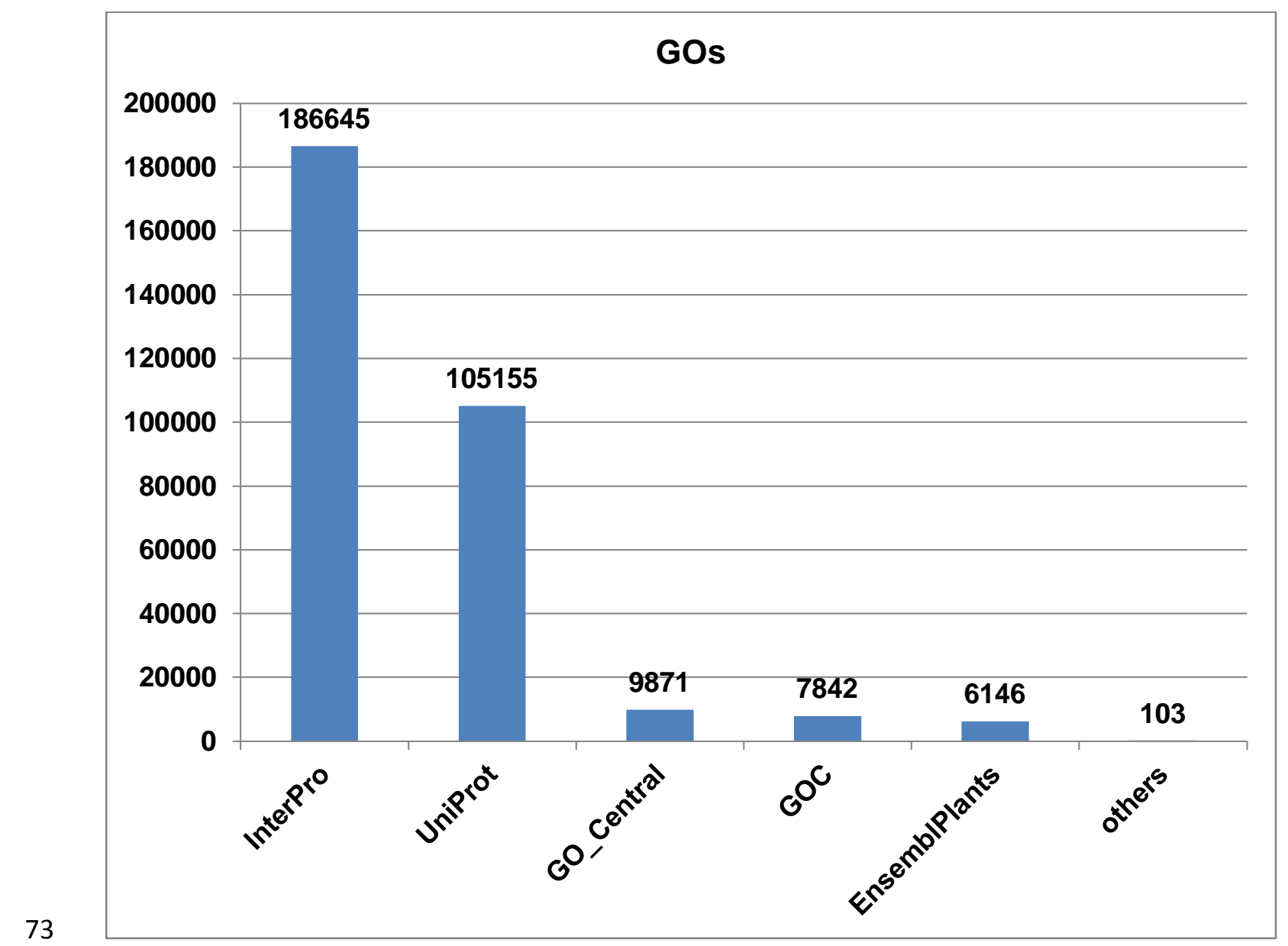

74 Supplementary Fig. S2: Annotation of Taverniera cuneifolia transcripts to different database sources. 


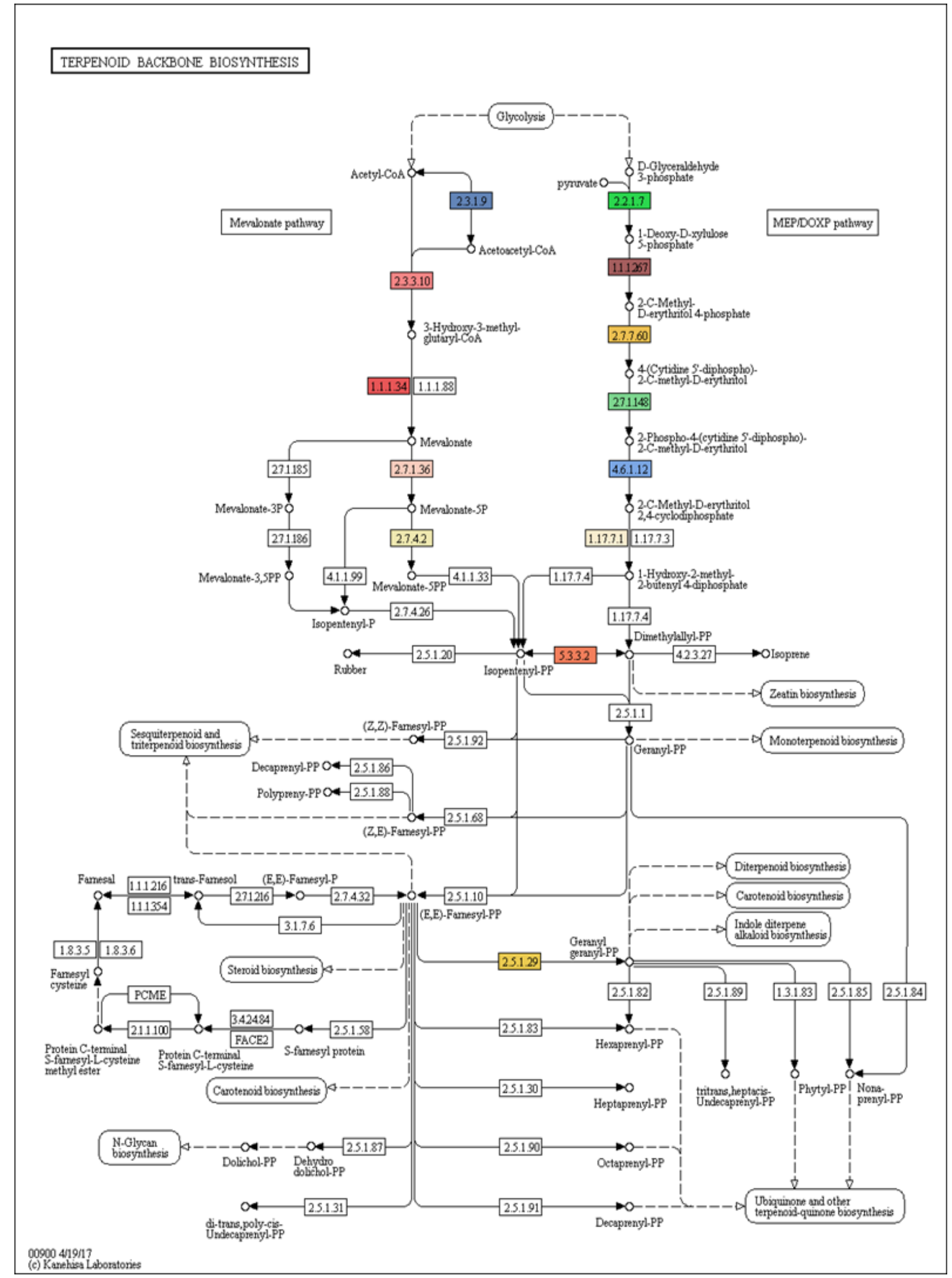

78 Supplementary Fig. S3: Terpenoids backbone biosynthesis pathways (Ko00900), color boxes are the gene found from Taverniera cuneifolia sequences. 
SESQUITERPENOID AND TRITERPENOD BIOSYNTHESIS

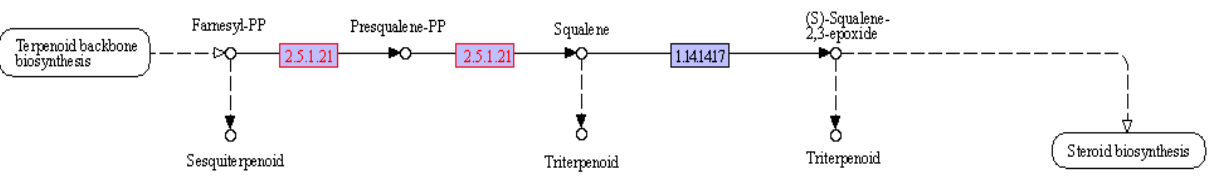

chair-chairchair-chair confomation

chair-chairchair-boat conformation

chair-boat-chair-boat confomation
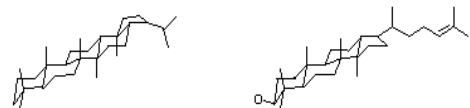

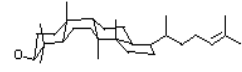

\section{Serquitepenoil}

Acyclic sesquiterpenoid

3.1.7. $\stackrel{\text { (E,E)-Famesol }}{\rightarrow}-1.1 .1354 \rightarrow 0$ (E,E)-Famesal

$5.2 .19 \rightarrow(\mathrm{ZE})$-Famesol

$4.2 .346 \rightarrow(\mathrm{E}, \mathrm{E})-\mathrm{ar}_{\mathrm{r}}$-Famesene

$4.2 .37 \rightarrow \mathrm{O}_{(\mathrm{E}, \mathrm{E})-\beta-\text {-Famesene }}$

$42.3 .48 \rightarrow 0(\mathrm{~S}, \mathrm{E})$-Nerolidol

$4.2 .3 .49 \rightarrow 0(3 \mathrm{R}, 6 \mathrm{E})$-Nerolidol

Bisabolene-type

epi-Iszizaene Abaflavenol

$42.3 .37 \rightarrow 0-11413106 \rightarrow 0-11413106 \rightarrow 0$ Albaflavenone

4 4.2.3.39 $\longrightarrow$ 8-epi-Cedrol

$4.2 .3 .38 \rightarrow 0(\mathrm{E})-\alpha$-Bisabolen

(S)- $\beta$-Bisabolene

$4.2 .40 \rightarrow 0(2)-y-$ - Bisabolene

$4.2 .59 \rightarrow 0$ (E)-y-Bisabole ne

$4.2 .6 \stackrel{\text { Trichodiene }}{\longrightarrow}-0-----\infty$ Nivalenol

4.2.3.24 $\rightarrow$ Amorpha-4,11-diene

$42.3 .50 \longrightarrow 0(+)-\sigma_{r}$ Santalene

$4.23 .69 \rightarrow 0(+)-a$-Barbatene

$4.2 .3 .78 \rightarrow O(+)-\beta$-Charrigrene

$4.2 .3 .79 \rightarrow 0(+)$-Thujopsene

$$
\text { Gemacren-type }
$$

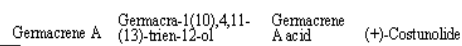
4.2.2.23 $\rightarrow 0-1.14 .1495 \longrightarrow 0-1.14 .1495 \longrightarrow 0-11414110) \longrightarrow 0$

4.2 .31 - $\rightarrow O$ Germacrene $B$

$4.2 .360 \rightarrow 0$ Gemacrene $\mathrm{C}$

$4.2 .375 \rightarrow(-)$-Germacrene D

Germacradienol

4.2.3.22 $\rightarrow 0-4.199 .16 \rightarrow 0$ Geosmin

Aristolochene

4.2.3. $\stackrel{\text { Anstolochene }}{\rightarrow}-0----\rightarrow O$ PR-toxin

(+)-5-Epiar-

4.2.3.61 $\stackrel{\text { stolochene }}{\rightarrow}$ - $1141414 \rightarrow \rightarrow$ Capsidiol

$4.2 .373 \rightarrow 0$ Valencene

Vetispiradiene

$4.2 .3 .66 \rightarrow 0$-Selinene

$4.2 .3 .76 \rightarrow 0(+)-2.5$ Selinene

4.2.3.86 $\rightarrow 0$ 7-epi-arselinene

$4.2 .3 .90 \longrightarrow$ 5-epi-arselinene

$4.2 .3 .70 \rightarrow$ Patchoulol

$4.23 .96 \rightarrow 0$ Avermitilol

Hurule ne-type

$4.2 .3 .57 \rightarrow 0 \beta$-Caryophyllene

(+)- $\beta$-Caryophylene

$42.3 .89 \rightarrow 0-42.1 .138 \rightarrow 0(+)$-Caryolan-1-ol

$423.137 \rightarrow 0$ (E)-2-epi- - -Caryophyllene

$42358 \rightarrow$ Longifolene

$4.2 .3 .56 \rightarrow 0$-Humulene

$423.104 \longrightarrow 0$-Humulene

Pentalenene

$\stackrel{\text { Pentalenene }}{\longrightarrow}-1.141532 \longrightarrow$ Pentalen-13-a

Cadinyl-type

4.2.3.13 $\stackrel{\text { S-Cadinene }}{\longrightarrow}-0----\rightarrow 0$ Gosypol

$4.2 .367 \rightarrow 0$ cis-Murola-3,5-diene
Triterpenoil chair-chair-chair-chair confomation

Hopene and Tetrahymanol

$42.1 .123 \rightarrow 0$ Tetrahymano

$42.1 .120 \rightarrow$ Hopan-22-01

$5.499 .17 \rightarrow \mathrm{Hop}-22(29)$-ene

$5.499 .37 \rightarrow 0$ Dammara-20,24diene

Triterpenoil chair-chair-chair-boat conformation

Protosteryl-type

$5.499 .32 \rightarrow 0 \quad \begin{aligned} & 1732)- \text { Protosta- } \\ & 17(20), 24 \text { dien-3 }-0\end{aligned}$

$5.499 .33 \rightarrow 0$ Cucurbitadienol

$5.499 .47 \rightarrow 0$ Parkeol

Dammarenyl-type

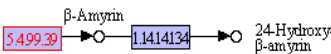

$5.499 .40 \longrightarrow 0$ arAmysin

$5.499 .41 \rightarrow 0$ Lupeol

$42.1 .128 \rightarrow 0$ Lupan-3ק,20-diol

42.1.125 $\longrightarrow$ D Damma-rene diol II

$5.499 .34 \rightarrow 0$ Germanicol

$5.499 .35 \rightarrow 0$ Taraxerol

$5.499 .36 \rightarrow 0$ Isomultiflorenol

$5.499 .52 \rightarrow 0$ a-seco-Amyin

$5.499 .54 \longrightarrow 0$ B-seco-Amynin

$5.499 .56 \rightarrow 0$ Tirucalla-7,24dien-33-ol

$5.499 .57 \rightarrow 0$ Barnol

Other-type

$5.499 .31 \rightarrow 0$ Thaliano

$5.499 .38 \rightarrow 0$ Camelliol C

$42.1 .124 \rightarrow \infty$ Arabidiol

$5.499 .48 \rightarrow 0$ Achilleol B

$5.499 .53 \rightarrow 0$ Mameral

Supplementary Fig. S4: Sesquiterpenoid and triterpenoid biosynthesis pathway (ko00909) highlighted boxes are the gene found in Taverniera cuneifolia sequences. 


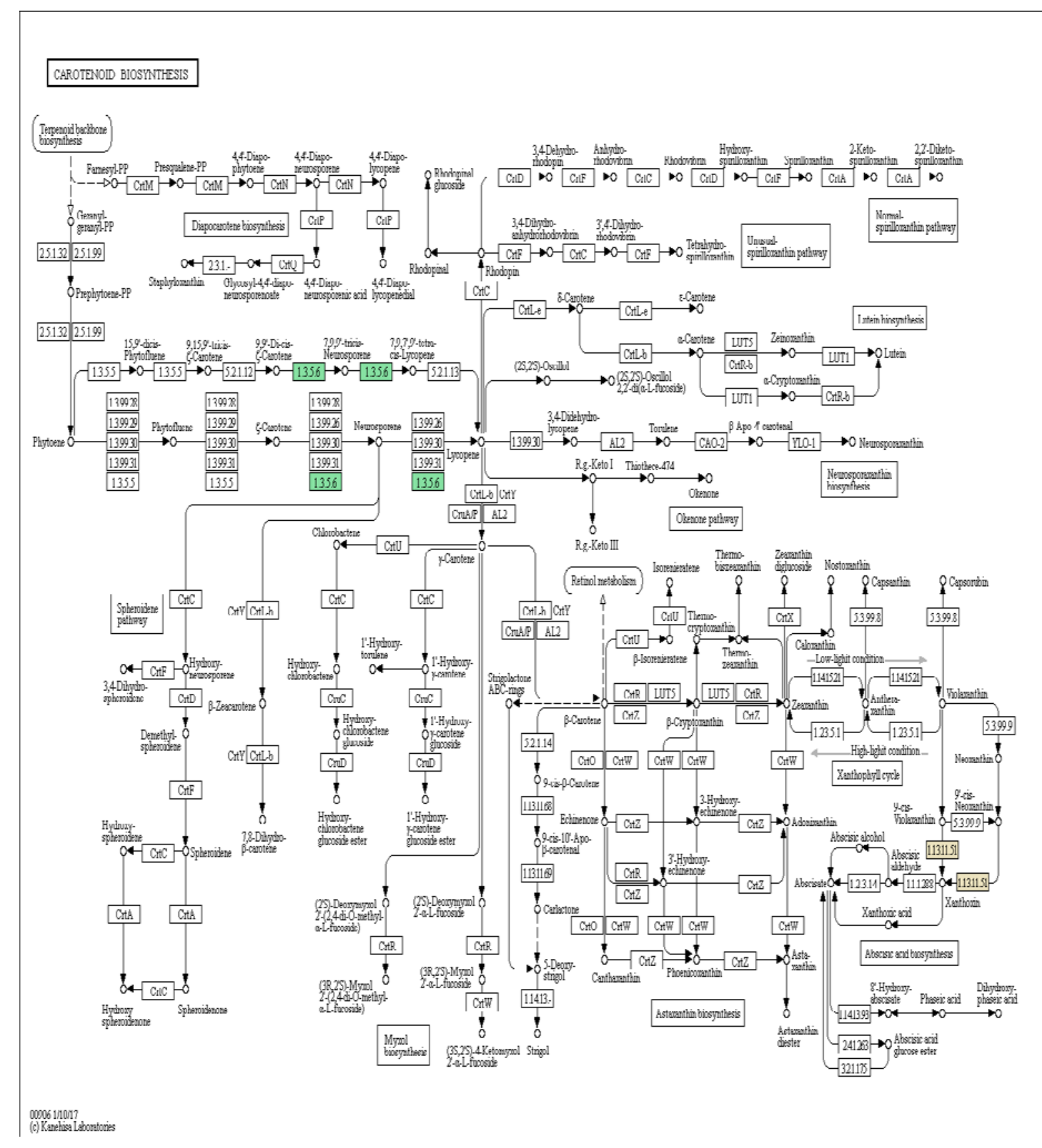

89 Supplementary Fig. S5: Carotenoid biosynthesis pathway (ko00906), color boxes are the gene found 90 in Taverniera cuneifolia sequences. 


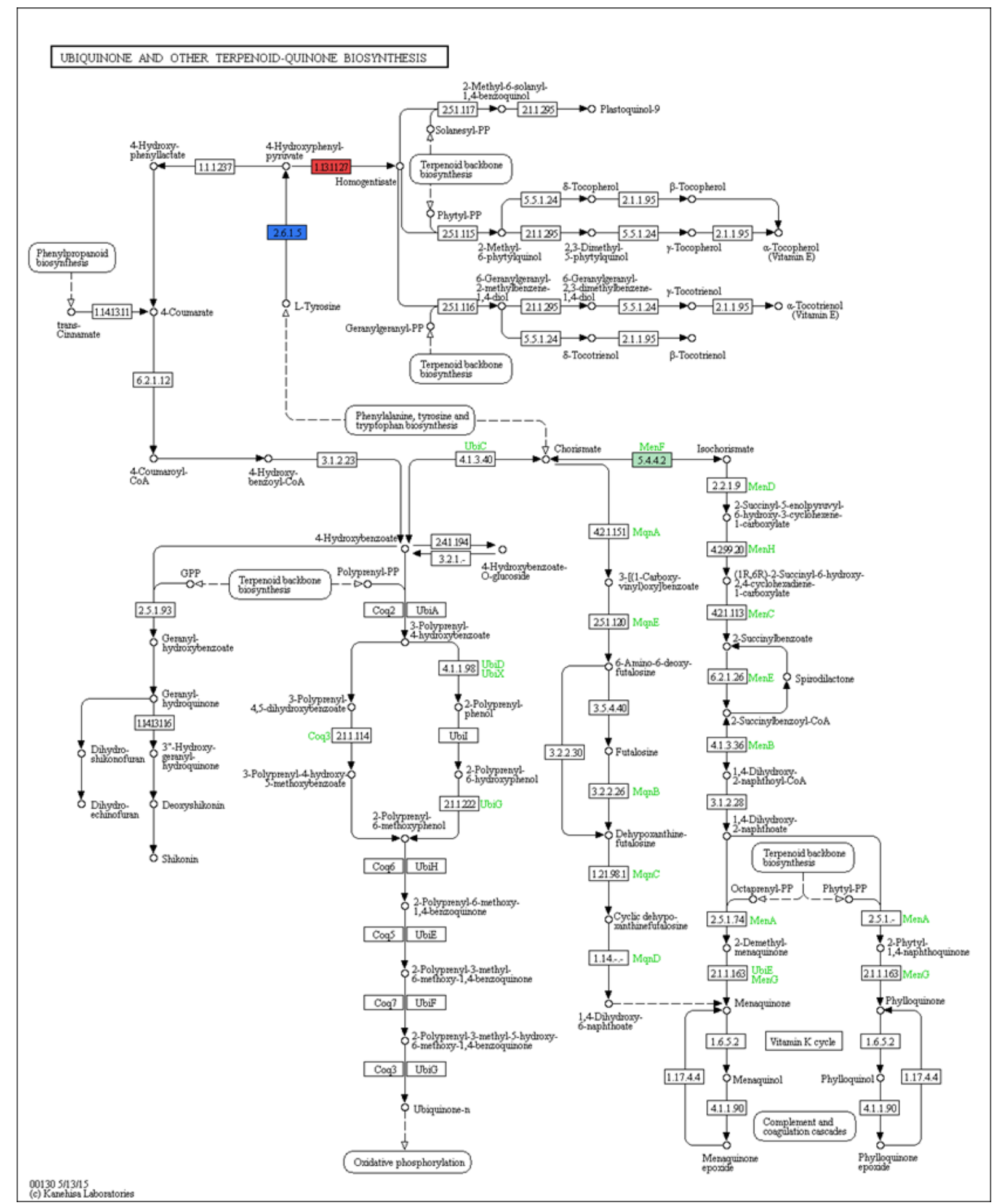

93 Supplementary Fig. S6: Ubiquinone and other terpenoid-quinone biosynthesis pathway (ko00130),

94 color boxes are the gene found in Taverniera cuneifolia sequences. 


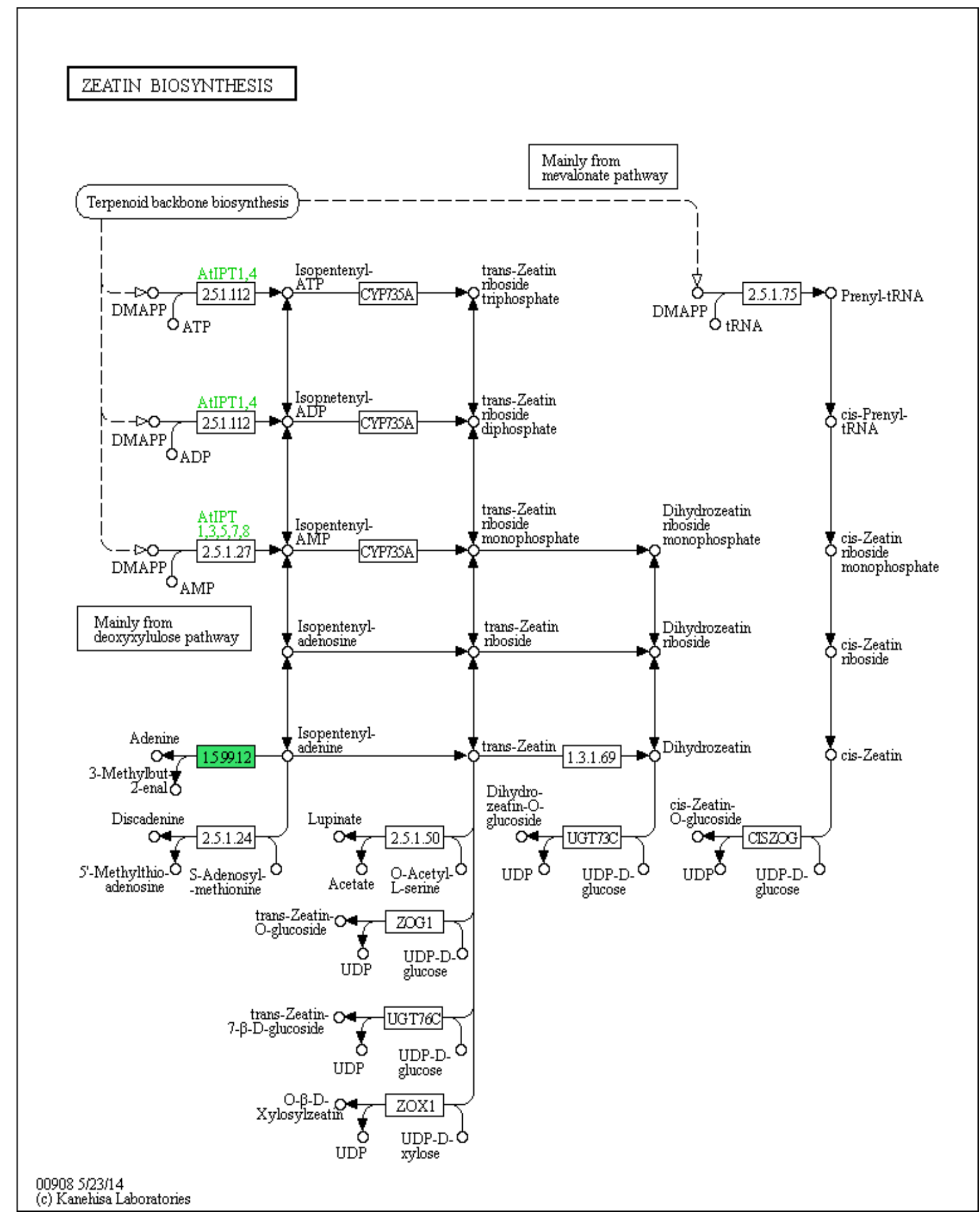

98 Supplementary Fig. S7: Zeatin biosynthesis pathway (ko00908), color box are the gene found in 99 Taverniera cuneifolia sequences. 


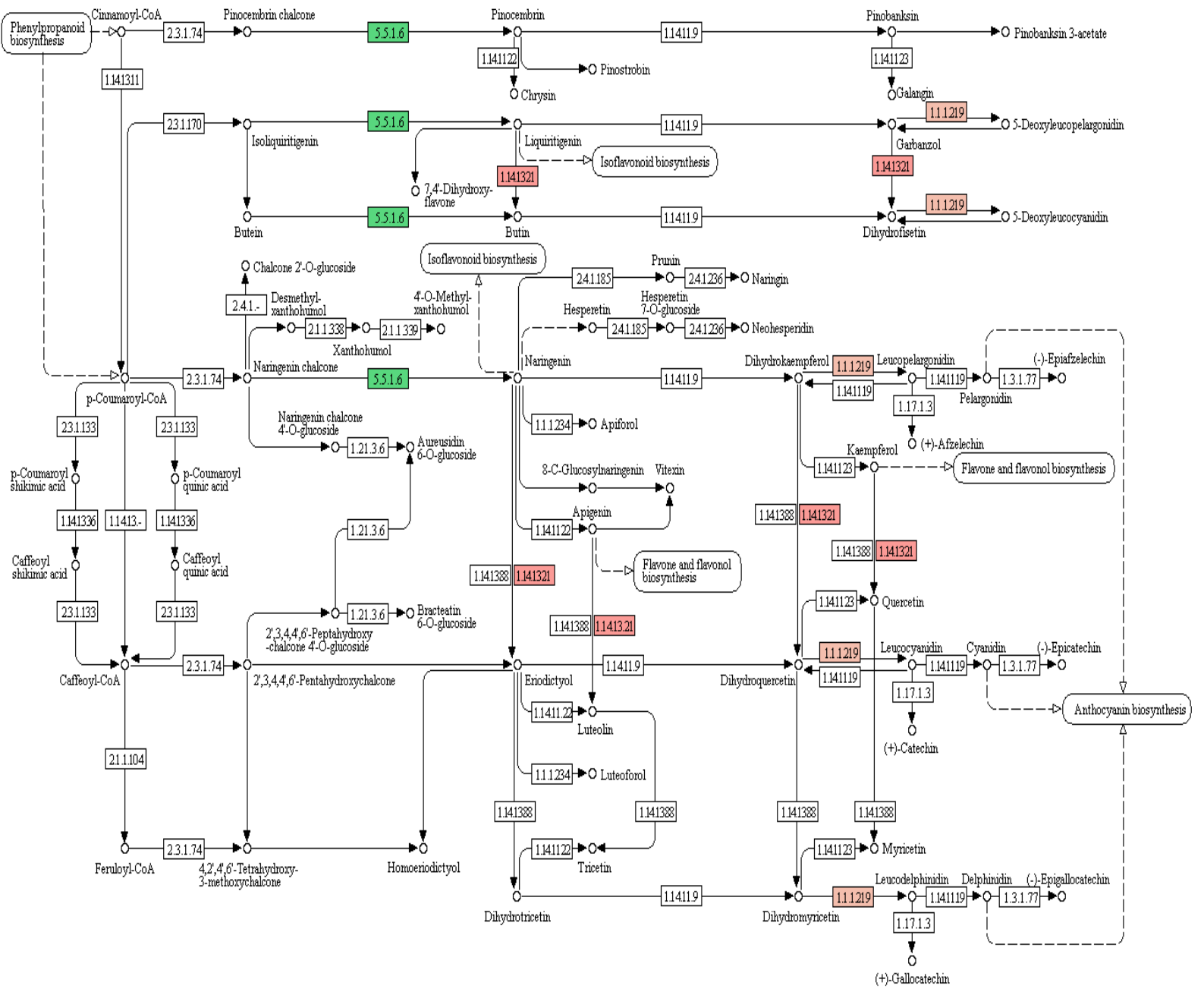

105 Supplementary Fig. S8: Flavonoid biosynthesis pathway (ko00941), color boxes are the gene found 
bioRxiv preprint doi: https://doi.org/10.1101/2022.01.27.477879; this version posted January 28, 2022. The copyright holder for this preprint (which was not certified by peer review) is the author/funder, who has granted bioRxiv a license to display the preprint in perpetuity. It is made available under ACC-BY-NC-ND 4.0 International license.

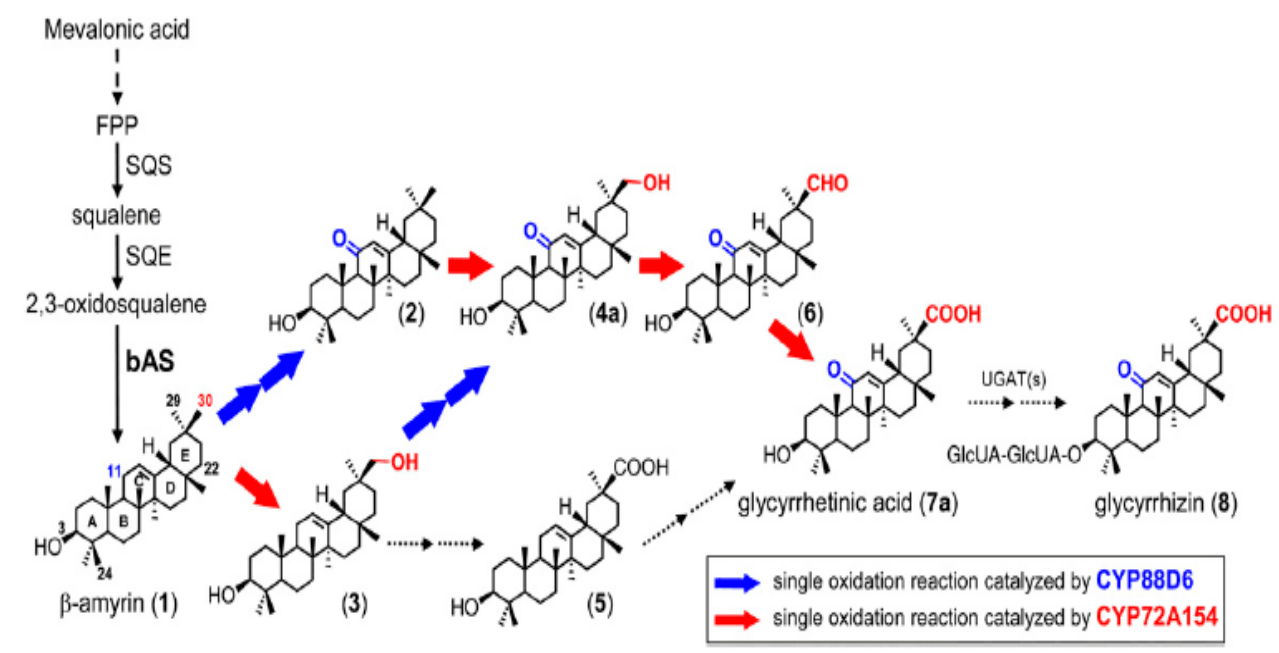

Figure 1. Proposed Pathway for Biosynthesis of Glycyrmizin.

The structures of possible biosynthetic intermediates between $\beta$-amyrin (1) and glycymhizin (8) are shown: (2), 11-oxo- $\beta$-amyrin; (3), 30-hydroxy- $\beta$ amynin; (4a), 30-hydroxy-11-oxo- $\beta$-amyrin; (5), 11-deoxoglycymhetinic acid; (6), glycyrnhetaldehyde; and (7a), glycymhetinic acid. Solid black arrows indicate a dimerization reaction of two farnesyl diphosphate (FPP) molecules catalyzed by squalene synthase (SQS) originating squalene, oxidation by squalene epoxidase (SQE) to 2,3-oxidosqualene, or cyclization catalyzed by bAS. A dashed arrow between mevalonic acid and farnesyl diphosphate indicates multiple enzyme reactions. The blue arrow indicates a single oxidation reaction catalyzed by the CYP88D6 enzyme (Seki et al., 2008); the red arrow indicates a single oxidation reaction catalyzed by the CYP72A154 enzyme, as described herein; the dotted arrows signify undefined oxidation and glycosylation steps. UGATs, UDP-glucuronosyl transferases.

111 Supplementary Fig. S9: Proposed Glycyrrhizin biosynthesis pathway in Liquorice roots by seki et al 2011 